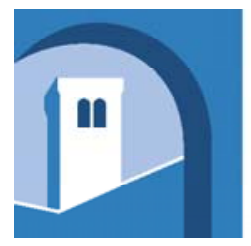

INTERACT - Researching Third Country Nationals' Integration as a Three-way Process - Immigrants, Countries of Emigration and Countries of Immigration as Actors OF INTEGRATION

Co-financed by the European Union

\title{
Residential Integration - Towards A Sending Country Perspective
}

\author{
Ben Gidley \\ Maria Luisa Caputo
}

INTERACT Research Report 2013/04 
INTERACT

Researching Third Country Nationals' Integration as a Three-way Process Immigrants, Countries of Emigration and Countries of Immigration as Actors of Integration

\author{
Research Report \\ Position Paper \\ INTERACT RR 2013/04
}

Residential Integration -

Towards A Sending Country Perspective

\author{
Ben Gidley \\ Maria Luisa Caputo \\ COMPAS
}


(C) 2013, European University Institute

Robert Schuman Centre for Advanced Studies

This text may be downloaded only for personal research purposes. Any additional reproduction for other purposes, whether in hard copies or electronically, requires the consent of the Robert Schuman Centre for Advanced Studies.

Requests should be addressed to migration@eui.eu

If cited or quoted, reference should be made as follows:

Ben Gidley, Maria Luisa Caputo, Residential integration - towards a sending country perspective, INTERACT RR 2013/04, Robert Schuman Centre for Advanced Studies, San Domenico di Fiesole (FI): European University Institute, 2013.

THE VIEWS EXPRESSED IN THIS PUBLICATION CANNOT IN ANY CIRCUMSTANCES BE REGARDED AS THE OFFICIAL POSITION OF THE EUROPEAN UNION

European University Institute

Badia Fiesolana

I - 50014 San Domenico di Fiesole (FI)

Italy

http://www.eui.eu/RSCAS/Publications/

http://interact-project.eu/publications/

http://cadmus.eui.eu 


\section{INTERACT - Researching Third Country Nationals' Integration as a Three-way Process - Immigrants, Countries of Emigration and Countries of Immigration as Actors of Integration}

Around 25 million persons born in a third country (TCNs) are currently living in the European Union (EU), representing $5 \%$ of its total population. Integrating immigrants, i.e. allowing them to participate in the host society at the same level as natives, is an active, not a passive, process that involves two parties, the host society and the immigrants, working together to build a cohesive society.

Policy-making on integration is commonly regarded as primarily a matter of concern for the receiving state, with general disregard for the role of the sending state. However, migrants belong to two places: first, where they come and second, where they now live. While integration takes place in the latter, migrants maintain a variety of links with the former. New means of communication facilitating contact between migrants and their homes, globalisation bringing greater cultural diversity to host countries, and nation-building in source countries seeing expatriate nationals as a strategic resource have all transformed the way migrants interact with their home country.

INTERACT project looks at the ways governments and non-governmental institutions in origin countries, including the media, make transnational bonds a reality, and have developed tools that operate economically (to boost financial transfers and investments); culturally (to maintain or revive cultural heritage); politically (to expand the constituency); legally (to support their rights).

INTERACT project explores several important questions: To what extent do policies pursued by EU member states to integrate immigrants, and policies pursued by governments and nonstate actors in origin countries regarding expatriates, complement or contradict each other? What effective contribution do they make to the successful integration of migrants and what obstacles do they put in their way?

A considerable amount of high-quality research on the integration of migrants has been produced in the EU. Building on existing research to investigate the impact of origin countries on the integration of migrants in the host country remains to be done.

INTERACT is co-financed by the European Union and is implemented by a consortium built by CEDEM, UPF and MPI Europe.

For more information:

INTERACT

Robert Schuman Centre for Advanced Studies (EUI)

Convento

Via delle Fontanelle 19

50014 San Domenico di Fiesole

Italy

Tel: +39055 4685817

Fax: + 390554685770

Email: migration@eui.eu 


\begin{abstract}
This position paper explores the key issues relating to how residential integration - a foundation dimension of migrant and minority integration - might be understood and further researched from a "country of origin" perspective. A series of questions are addressed: Are there transnational residential strategies of migrants? Is residential integration an indicator of integration, e.g. can owning a house be an indicator of integration? Are residential patterns in the receiving country negotiated in any way by the state of origin? And what is the role of home country institutions in assuring residential integration or separation? Looking at the nature and quality of the housing that minorities occupy, assessed in terms of factors such as tenure, overcrowding and disrepair, and at the patterns of migrant residence in receiving societies, including clustering or its absence, the paper covers the existing state of the art and methodology used in the field, before arguing for a shift to a country of origin perspective, beyond simply using country of origin as a variable in determining residential integration outcomes, but instead re-framing the issue in a transnational perspective. It introduces a new theoretical and methodological framing, shifting the emphasis from a static "social physics" to a processual, pathwayfocused approach.
\end{abstract}




\section{Introduction}

This position paper explores the key issues relating to how housing integration might be understood and further researched from a "country of origin" perspective. Residential integration is a key and perhaps even foundational dimension of the integration of migrants and minorities. Residential integration includes two key elements: the nature and quality of the housing that minorities occupy, assessed in terms of factors such as tenure, overcrowding and disrepair; and the patterns of migrant residence in receiving societies, including clustering or its absence. Residential integration in the second sense is usually seen as opposite to residential segregation, although, as we shall see below, segregation itself is defined in multiple ways, in terms of uneven distribution of settlement and low chances of inter-ethnic contact, as well as concentration, centralization and clustering. "Clustering” itself is a more neutral term, referring to the propensity of specific groups to live together, rather than to their separation from other groups.

The issues of overcrowding and housing quality have been a major concern of migrant organisations and advocates as an index of the discrimination and disadvantage migrants face, while segregation and the formation of migrants enclaves and ghettos have played a central role in the public imagination of the policy field. A recent Eurobarometer qualitative snapshot of migrants' and non-migrants' attitudes to integration found that residential segregation, and specifically the formation of "ghettos", was seen by non-migrants as the most important barrier to successful integration (TNS Qual+ 2011).

The first part of this position paper covers the existing state of the art and methodology used in the field, in relation to both elements. It briefly introduces the main issues then explores the main methodological approaches. In the second part of the paper, suggestions are made, drawing on the literature, for a move to a country of origin perspective on residential integration, starting with country of origin as a variable in determining residential integration outcomes, re-framing the issue in a more transnational perspective. The third part highlights the gaps in the literature, and the fourth introduces a new theoretical and methodological framing, shifting the emphasis from a static "social physics" to a processual, pathway-focused approach.

A series of key questions, identified by the INTERACT project, will be addressed: Are there transnational residential strategies of migrants? Is residential integration an indicator of integration, e.g. can owning a house be an indicator of integration? Are residential patterns in the receiving country negotiated in any way by the state or origin? And what is the role of home country institutions in assuring residential integration or separation?

The main issues in the field fall within the two elements already mentioned. In terms of the first, the nature and quality of migrant housing, this includes the following issues:

- Tenure and ownership: The large body of international literature on different forms of housing tenure tends to show that, even controlling for other variables, migrants are less likely to achieve home ownership, and that there is some correlation between home ownership, length of residence and civic participation, but also that there is some correlation between residential segregation (ethnic enclaves) and the achievement of home ownership (Borjas 2002, Bourassa 1994, Constant et al 2009, Coulson 1999, Duffy 2007, Hirschman 1994, Logan and Alba 2002, Massey 1985, McConnell and Akresh 2008, Mesch and Mano 2006, Myers and Lee 1998, Painter et al 2001, 2003, Painter and Yu 2008, Yu 2006). As will be explored below, country of origin dynamics can play a part in this element of residential integration (Alba and Logan 1992, Papademetriou and Ray 2004).

- Overcrowding and housing conditions: There is also a significant body of evidence on migrant housing conditions, again pointing to gaps between migrant outcomes and 
those of non-migrants, with many categories of migrants often experiencing overcrowding or poor housing conditions, as well as declining rates of overcrowding following long-term residence. However, from the literature there is little likelihood that sending country dynamics play a significant role in this (Myers and Lee 2006).

In terms of geographical residential patterning, the key issues are:

- Segregation and clustering: There is an extensive literature on migrant settlement patterns which focuses on the extent to which migrants are residentially concentrated in particular areas. Again, as will be discussed in this paper, sending country dynamics might play a role in shaping this element of residential integration.

As we will see below, the measurement of integration in this domain is challenging and the relationship between integration in this domain and in others is far from straightforward. Nonetheless, we suggest that residence is fundamental to a full understanding of integration, because local place is the primary site of migrants' everyday interactions with a receiving society. When Third Country Nationals arrive in EU member states, it is in specific places most often, but not always, inner city neighbourhoods - that they arrive. Place matters, and the nature of the place of settlement makes a fundamental difference to the different stages of the integration process.

\section{Understanding residential integration}

Having defined the key issues, how have social scientists researched these issues? What are the key sources of data, and what are the limits on these? Historically, the study of integration in general and of residential integration in particular has been bound up with the study of the city. The emergence of modern social science was in part a response to the formation of the modern city; the mass migration from country to town in the wake of the industrial revolution generated new forms of behaviour and social problems calling for scientific attention. The study of integration has its roots in this moment, and in particular in Durkheim's work La division social du travail (1893). Durkheim interpreted integration as the degree of sharing of common rules and values. He spoke of "moral density", the "moral rapprochement" produced by the reduction of spatial distance between individuals. Nonetheless, he argued, this proximity is necessary but not sufficient to provide integration; therefore, against the dissolution of the social rules in the urban context and the rise of the individual, Durkheim postulated the necessity of communities.

In the 1900s, Georg Simmel re-elaborated Durkheim's analysis in the terms of social psychology. Simmel describes the process of "de-socialisation", such as the loosening of the link between the individual and his community. He believed that the oldest form of social groups is that of a strongly cohesive community. In this kind of group, the individual has limited autonomy and liberty of movement. This kind of community is presumed to grow in the urban context numerically, spatially and culturally; its internal unity and its boundaries become less strong because of the exchanges and the connections; the individual obtains more liberty of movement. Thus despite physical proximity, social distance between individuals is maintained; the characteristic figure of the city, therefore, is the "stranger". In the modern city, Simmel argued, the stranger comes today but stays tomorrow. Although it is now clear that it is not just in cities that issues of integration present themselves - and indeed, as we shall see below, a body of work is emerging on rural and suburban dynamics of settlement the urban context of the question's emergence was sustained through the main methodological approaches in the last century. 


\subsection{The American literature: ghetto as peculiar institution}

Our scholarly literature on residential segregation emerged in the United States early in the twentieth century. The first serious scientific study to address the issue was The Philadelphia Negro (1901), written by the pioneering African-American sociologist WEB DuBois, which drew on household interviews and census data to portray the city's black community to explore the residential concentration of blacks in the Seventh Ward, mapping the community by class and "character" to show a bounded and contained but internally heterogeneous population. The urban "ghetto" - as spatial concentration of a subaltern minority emerging in the metropoles of the American North in the period of the post-slavery "Great Migration" from the rural South became the paradigmatic space for the scholarly discussion of segregation, and indeed of race and ethnicity more generally. However, the segregation of African-Americans must be seen as an American exception, one of the "peculiar institutions" which enabled the perpetuation of the paradox of the ideal of democratic egalitarianism and the reality of black exclusion: AfricanAmericans were "constructed symbolically and handled institutionally, not merely as noncitizens laying outside of the inaugural social compact of the republic, but as veritable 'anticitizens' standing over and against it” (Wacquant 2005:136).

Following DuBois, a sociology of urban settlement patterns emerged in America. The reflection of the German sociologist Georg Simmel strongly influenced the Sociological School formed in Chicago from 1916 and its perspective of "human ecology": the analysis of human relations, social and ethnic communities, and their development in the city. The city was represented by human ecology as a habitat which naturally sorted and sifted its social groups into a mosaic of "natural areas": within these segregated areas, the community forms a cultural independent unit, with its own cultural and social models.

With Chicago as their laboratory, Robert Park and his colleagues explored its Little Sicily and its Chinatown as instances of this ecological tendency; the ghetto (Wirth 1928) was their exemplary image of immigrant clustering. Park (1925) theorised that physical distance (of the ghetto's inhabitants to the mainstream world) generated social distance, and thus that patterns of assimilation in other spheres of life could be mapped on to urban settlement patterns. Duncan and Lieberman (1959) used larger scale evidence to show segregation as the inverse of assimilation. However, the foregrounding of race and ethnicity - with ethnic groups seen as naturally occurring within the urban ecosystem - remained dominant in this literature.

New contours of urban settlement in the 1970s/80s saw the emergence of migration-focused literature, such as the work of Massey and Denton on migrant-origin Asian and Hispanic segregation, seen as differently patterned than that of black Americans. Since then, the sociospatial dynamics of American ethnicity have continued to mutate, with some groups becoming less segregated and others more, with social mobility ever less isomorphic with spatial deconcentration; new academic agendas have consequently emerged with new "gateway cities", the "ethnoburb", and other motifs emerging in the literature. Among the consequences of this shift has been a growing recognition of the diversity of outcomes for different country of origin groups (e.g. Denton and Massey 1989, Yu and Myers 2007, Li 1998).

\subsection{The European literature: beyond ethnic framing, towards migration framing}

As European societies became sites of immigration, the theme of residential integration returned here. The European literature historically took the US literature as its model, but rapidly moved beyond the American ethnic framing, and towards migration framing (Bergamaschi and Ponzo 2011). In "older" migration countries, such as the UK, attempts were made to use similar methodologies to understand distinct patterns - a question framed by Peach as "Does Britain have ghettoes?" Peach argued that whereas New York, for instance, is a city of immigrants and minorities, London is a city with immigrants and 
minorities (1996). In the "British model" that Peach identified, "culture" (i.e. the specific cultural practices of particular ethno-cultural groups) rather than "race" was the fundamental divide. Whereas American cities experienced suburbanisation as "white flight", European cities saw declining population in the mid-twentieth century period before large-scale inmigration, leaving affordable urban space which migrants accessed.

Consequently, the weight of the research showed that European cities have far lower levels of spatial concentration by ethnicity than their American counterparts, a finding confirmed, for example, in the Netherlands (e.g. Musterd and Ostendorf 1998, 2007), Sweden (e.g. Andersson 2007). European cities do include sites of migrant residential concentration, but migrant populations as a whole are less intensely clustered.

One significant factor which shapes the housing dynamic in older migration countries in Europe is the huge role of public housing in the urban residential market, which dramatically shapes housing outcomes for many migrant groups. Thus different sorts of housing policies and welfare entitlements across Europe play a much more significant role in the literature here than in the US (Fortuijn et al 1998).

Despite the low levels of enclaving in Europe compared to the US, there has nonetheless been a powerful policy discourse around "parallel societies" (Parallelgesellschaften) in several different European countries, especially older migration contexts such as Germany, the Netherlands, France and the UK, sometimes linked to spectacular incidences of urban unrest, as with the French banlieue uprisings of 2005 (Schönwälder 2007). In the next section, we will briefly set out the contemporary context in which residential integration unfolds, before moving in detail to the key methodological approaches to the issue. It is also worth noting that the existing literature tends to concentrate on documenting segregation in European cities, and not on migrants' own experiences, perceptions and opinions of this (Kohlbacher and Reeger 2005).

\subsection{Comparative research across Europe}

Comparative research has been a strong feature of the European literature, with comparisons conducted at a number of levels, from the national to the regional to the city and even neighbourhood.

Throughout the 1990s, immigration scholars in Europe focused on the nation state as the key level for understanding immigrant integration comparatively (Brubaker 1992; Heckmann and Schnapper 2003; Schnapper 1992; Soysal 1994; Zincone 1991). The importance of the different national integration models or philosophies of integration posited by scholars such as Favell (2001) and Joppke (1998) and the different immigration policies and migration histories features prominently in the research. Different national models - such as the Dutch "multicultural", the British "race relations" model, the French "assimilationist" model and the German "differentialist" model (Koopmans and Statham 2000) - embodied in varying regulatory frameworks, policies and practices, shape variations in the possibility of residential integration from country to country.

The critique of methodological nationalism associated with the "transnational turn" in migration studies (e.g. Wimmer and Glick-Schiller 2002 or more recently Michel Wieviorka 2008, 2009) has exposed the limits of such nationally scaled comparisons. One direction in comparative scholarship has seen the emergence of work on regional "types" as well as national models. For instance, in addition to Northwestern European literature on the inner city and the ethnic banlieue, a distinctly Southern European urbanism literature has explored the spread of "vertical segregation" whereby migrants are concentrated on upper floors of housing blocks (as in Northern Italy) or on lower floors (as in Greek cities). 
More frequently, the turn against methodological nationalism has shifted comparative analysis to the city level (Penninx et al 2005). An underdeveloped field of cross-city comparisons has been more prominent in the last decade (Zincone and Caponio 2005). There have been important attempts to map and typologise different sorts of "contact zones" (e.g. Robinson and Walshaw 2012, Hickman et al 2012, Wallman 2011).

Most recently, a critique of "methodological city-ism" has emerged with an insistence that the neighbourhood, as integration's "ground zero", is the most appropriate scale for comparative analysis of the real processes of integration (Pastore and Ponzo 2013). This turn to city and neighbourhood approaches in the comparative literature is thus able to draw on the insights of the urban sociological literature noted above, as well as the growing new body of comparative urbanism (e.g. McFarlane and Robinson 2012, Nijman 2007, Ward 2010). Glick Schiller and Çağlar (2009) call for a "rescaling" of migration studies to better calibrate it to the challenges of understanding these place-specific processes. Such a re-scaling would require migration studies to enter into closer dialogue with geography, urban studies, and other more spatially attuned disciplines. Wei Li's analysis of the emerging Chinese "ethnoburb" in the American metropolis of the 1990s gives us some indications: "global and national conditions manifest themselves at the local level, and are overlaid onto the place-specific situations. The interplay of changing geopolitical, economic and social dynamics at different levels and their spatial expressions form new opportunities for an ethnoburb to be created at certain localities” (1998:482). Wei describes the ethnoburb as an outpost of a global community, in which residents are typically simultaneously involved in international trade and related services and active players in the restructured local economy. It is this global dimension which makes ethnoburbs distinct from older ethnic enclaves.

\subsection{Drivers of residential integration and segregation}

All of these literatures, American and European, have yielded valuable hypotheses on the drivers of residential integration. These include what Simpson et al call "dysfunctional processes" that prevent integration and "benign processes" that produce areas of different ethnic compositions (2007: 6). We can identify four main sets of drivers of residential integration and segregation: discrimination, ethnic majority revanchism, housing market factors, and social factors.

A massive literature, both activist and scholarly, has focused on areas of discrimination faced by migrants and minorities, including the housing market. This includes both formal mechanisms and informal mechanisms, ranging from the prejudices of landlords and lenders to institutional racism among public housing providers. In addition to direct forms of discrimination, indirect discrimination may result from lack of information about housing (for instance advice about public housing entitlements or about access to cheap finance) or from language barriers which block new migrants' access to information.

"Revanchist urbanism", a term used in critical geography, refers to the processes by which majority populations attempt to withdraw themselves from the diversity of the city. This includes the creation of exclusive gated communities and processes of "white flight", as majorities remove themselves from areas perceived to be multicultural.

Housing market factors are fundamentally important. As with non-migrants, the socioeconomic characteristics of the migrant household are key determinants of tenure, conditions and residential location. Household financial resources are especially important in determining choices about what is affordable, and these in turn rest on access to credit.

These household level factors are mediated by immigration status and the rights and entitlements associated with these, including the right of residence and access to public housing or rent support. In different welfare systems, housing need (which is often 
demonstrable among refugee families, for instance) might facilitate access to public housing, while in other welfare systems length on the waiting list or residence in a municipality will help determine this (thus disadvantaging recent migrants).

And these household level factors interact in complex ways with housing supply and prices, determined largely by the market and by the regulatory environment.

In emphasising market factors, it is important to bear in mind the role of historical conjuncture and opportunity in structuring housing choices. For example, Caribbean migration to London occurred at a time when extensive war-time bomb damage had particular effects on the private rental housing market, while slightly later South Asian migrants to the same city were able to access openings in the housing market caused by "counterurbanisation" patterns of flight from the inner city. Similarly, the economic crisis after 2008 means new migrants have very different opportunities from those arriving in preceding periods.

Some of the key concepts in the literature around residential integration relate to the pull factors in residential clustering. These include the locational, contextual and personal characteristics which drive clustering (e.g. Glavac and Waldorf 1998). Wei Li's work on the Chinese "ethnoburb" in Los Angeles is an example of this, showing that the concentration of Chinese places of business and employment both drive and are driven by residential clustering, with lower rates of in- and out-commuting than more typical US suburbs, thus maintaining some of the features of older ethnic enclaves (1998:484). For many migrants with curtailed financial and social capital in a receiving society, residential clustering also enables strong ties (bonding capital) that support their livelihood strategies while leaving them "encapsulated" in “truncated” networks (Portes 1998, Granovetter 1983, Ryan 2011).

There are also different spatial and temporal orders of clustering discussed in the literature, such as the existence of primary and secondary clusters and the divergence between initial residential choice on migration and subsequent moves which have the effect of relatively weakening or strengthening primary or secondary clusters or of driving deconcentration (e.g. Glavac and Waldorf 1998).

The role of chain migration and migrant networks (to which we will return below as we focus on a transnational approach to residential integration) is key here, with chain migration producing clustering effects, which in turn encourages more migration: the formation of ethnic enclaves or at least a critical mass of co-ethnics in a city or neighbourhood makes settlement more attractive, while those who settle first take on key intermediary and networking roles in facilitating future migration (see e.g. Gardner 2002 on Bangladeshis in London).

\subsection{Is residential integration an indicator of integration?}

A related key set of questions is around the measurement of residential integration, and the extent to which it can be measured as an indicator of integration more broadly. Media and policy discourses around parallel lives and segregation suggest that migrant spatial concentration is a key indicator of integration as understood publicly.

The academic consensus is that residential integration is indeed an indicator of integration in general. The Chicago school model was fairly one-dimensional, a form of "social physics" (Peach 1975), which straightforwardly correlated spatial distance with social distance and thus an inverse relation between residential concentration and assimilation.

More recently, for example, in Ted Cantle's work (2001) on community cohesion, as in many other accounts, social interaction is closely related to the places where people are housed, schooled and employed. The reports which followed the UK's milltown disturbances in 2001 emphasised residential clustering, described as "sleep-walking into segregation”, as creating 
problems of cohesion, and UK government policy since 2001 has increasingly seen ethnic clustering as socially problematic and negatively impacting on cohesion (Ousely 2001, Ritchie 2001, Denham 2002, but see also Bagguley and Hussain 2006; Burnett 2004, Kalra 2002, Kundnani 2007, McGhee 2008). And elsewhere in Europe, there is evidence of some correlation between residential integration and integration in the labour market - as in Italy, where Moroccan migrants have a longer presence than Romanian migrants but are less residentially integrated in a way that correlates to their relative exclusion from the Italian labour market (Ponzo 2009) - and education integration - as the school choice and residential choice of migrants and non-migrants are clearly related.

However, as this "dissimilarist" approach has built up increasingly complex and contradictory evidence, the picture has become more complicated. There has been a growing recognition of the relative autonomy of the different domains of integration. Early interventions included Ramsoy (1966), whose research in Oslo showed the autonomy of "propinquity and homogamy” from segregation, and Boal (1969) who separated "activity segregation” from residential segregation.

Thus an increasing weight of evidence pushes against the original thesis and suggests that migrants benefit in several ways from living near people of the same background, and that this can be a factor for successful integration in a number of domains, including the labour market (Robinson and Reeve 2006, Murdie and Borgegård 1996). Analysis of the UK Home Office Citizenship Survey has found that the religious and ethnic concentration of a neighbourhood is statistically insignificant to a sense of belonging and identity with Britain across all groups (Maxwell 2006). Robinson and Reeve claim that evidence suggests that "new immigrants are making a positive contribution to... the cultural and social fabric of towns and neighbourhoods and, in some situations, the regeneration and revitalisation of declining neighbourhoods" (2006:1). Similarly, Papillon writes that the spatial concentration of immigrants "may not necessarily be a problem: it may contribute to the creation of social networks and facilitate access to employment; but it may also, when combined with poverty, become an explosive mix, leading directly to the social exclusion of future generations" (2002:iii). Most optimistically, Simpson et al argue that "Cultural and family clustering is also positively helpful to the integration of new immigrants and their families, who develop social networks whose sympathy and experience support them in the search for work and housing. The benign and often positive aspects of residential clustering have not been given sufficient recognition in reports on social cohesion for the government in this decade. For these reasons the success of integration cannot be measured by the absence of residential clustering. Residential clustering will continue due to benign processes irrespective of the success in reducing dysfunctional processes” (2007: 8).

Areas with high numbers of people from migrant backgrounds already living there "can be rich in various resources vital to helping new immigrants meet the challenge of satisfying their material needs, coping with hostility and discrimination, engaging with key services and negotiating a place in British society" (Robinson 2006:2). Ager and Strang (2008:178) cite the evidence of Hale (2000) and the extensive review of evidence by Duke et al (1999), which show that connections with fellow migrants reinforced by residential proximity strengthen social capital, especially "bonding" capital. Hence, in developing indicators of refugee integration, Ager and Strang initially proposed a suite of indicators to do with housing which included "measures of the physical size, quality and facilities of housing, along with the financial security of tenancies and, where appropriate, ownership". But they found in their fieldwork with refugees that these aspects of housing were considered unimportant; what was considered important were the sense of being settled and at home in an area (2008:171) - the aspects of housing that point beyond the socio-economic towards identity and belonging.

More sophisticated attempts to measure residential integration using such indicators would be able to compare similar country of origin groups in different spatial settings, to better 
understand the relationship between neighbourhood effects and country of origin effects, as in Wei Li’s (1998) analysis of Chinese ethnoburbs.

Finally, underlying all the processes of integration is the regulatory regime which enables or prevents migrants from equally participating in the various domains; this web of legal rights and responsibilities form a foundation for integration. In the domain of residential integration, most relevant would be laws and rules relating to the long-term settlement of migrants with different legal status, but also laws and rules relating to their entitlements to some welfare benefits including housing assistance and, crucially, access to public housing.

\subsection{Measures of residential integration and segregation}

\subsubsection{Quantitative methodologies}

Understanding such factors has required the development of methodologies for measuring integration and segregation. As noted in the introduction to this paper, residential tenure and conditions have been used as key indicators of integration, along with features related to segregation. Variables relating to tenure and conditions are relatively straightforward in their measurement.

Issues relating to segregation are more complex and contested. In their analysis of segregation's dimensions, Denton and Massey (1988) considered residential segregation as a multidimensional phenomenon varying along five distinct axes of measurement: evenness (uniformity of distribution), exposure (chance of being in contact), concentration, centralization, and clustering. O'Sullivan and Reardon in 2004 discussed Denton and Massey's paper in their distinction between spatial and a-spatial traits of residential segregation. They reduced the study of residential segregation to two main dimensions: spatial exposure or spatial isolation (the extent that members of one group encounter members of another group or their own group, in the case of spatial isolation in their local environments) and spatial evenness or clustering (the extent to which groups are similarly distributed in residential space) (Figure 1). 
Figure 1. Main dimensions of segregation ( $O$ 'Sullivan and Reardon, 2004)

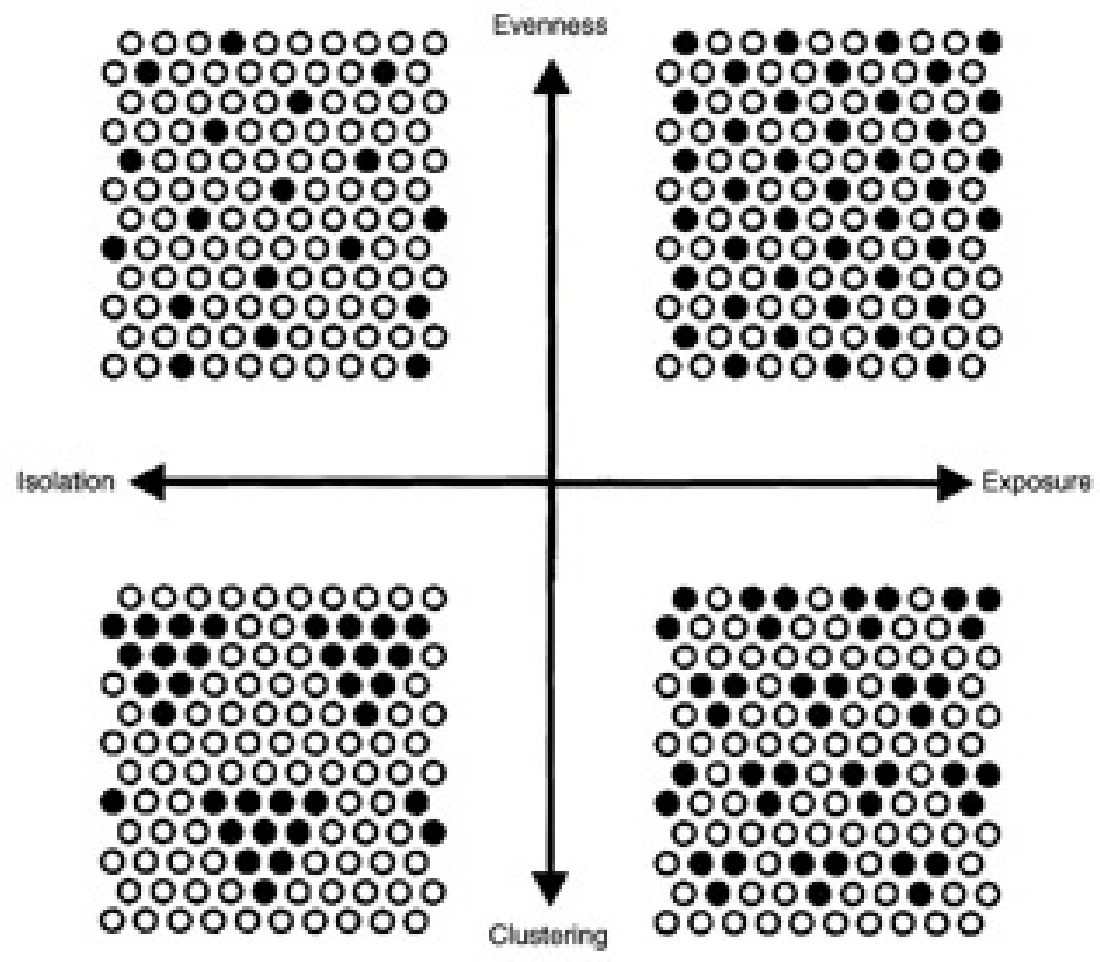

Evenness is a relative measure and refers to the differential distribution of two social groups among areal units in a city. It is maximized when all units have the same relative number of the two group members as the city as a whole and minimized if a group is distributed in an elevated heterogeneous way over areal units.

Therefore, the evenness indices express the degree of distributional heterogeneity between two populations. They reflect the degree of heterogeneity in the composition of the population, which are considered as both divided sub-groups and independently from how these sub-groups are distributed. In this sense they are a-spatial.

The most widely used measures of residential evenness are the Dissimilarity Index (DI), the Gini coefficient and the Entropy index:

The Dissimilarity Index assesses the evenness with which two groups are distributed across the component geographic areas that compose a larger area. Its basic formula is:

$$
\begin{aligned}
& 1 / 2 \sum-\left|\mathrm{x}_{\mathrm{i}} / \mathrm{X}-\mathrm{y}_{\mathrm{i}} / \mathrm{Y}\right| \\
& 1<\mathrm{i}<\mathrm{n} \\
& \mathrm{x}_{\mathrm{i}}=\text { the number of members of the group } \mathrm{X} \text { in the } i^{\text {th }} \text { area, e.g. census tract } \\
& \mathrm{X}=\text { the total population of the group } \mathrm{X} \text { in the large geographic entity } \\
& \mathrm{y}_{i}=\text { the number of members of the group } \mathrm{Y} \text { in the } i^{\mathrm{th}} \text { are } \\
& Y=\text { the total population of the group } \mathrm{Y} \text { in the large geographic entity }
\end{aligned}
$$

The critics of the DI were concerned with its correlation to the number of sub-areas and their conformation. In the nineties, an alternative formula was proposed that took in account the spatial characteristics of the sub-areas (Morrill 1991; Wong 1993). 
The Gini Index is closely related to the index of dissimilarity and represents the mean difference between minority proportions weighted across areal units, expressed as a proportion of the maximum weighted mean difference.

The Entropy index measures the distance from evenness by assessing each unit's difference from the entropy of the whole city. A city's entropy is the extent of its diversity. The Entropy index is calculated as:

$$
\mathrm{E}=-\sum\left(\mathrm{x}_{\mathrm{i}} / \mathrm{X} \cdot \ln \mathrm{x}_{\mathrm{i}} / \mathrm{X}\right)
$$

Where:

$1<\mathrm{i}<\mathrm{n}$

$\mathrm{x}_{\mathrm{i}}=$ the number of members of the group $\mathrm{X}$ in the $i^{\text {th }}$ area, e.g. census tract

$\mathrm{X}=$ the total population of the group $\mathrm{X}$ in the large geographic entity

Residential exposure refers to the degree of potential contact or the possibility of interaction between two groups. Indices of exposure measure the degree of confrontation by virtue of sharing a common residential area. Although indices of exposure and evenness tend to be correlated empirically, they are conceptually distinct because the evenness indices depend on the relative size of the groups, while the exposure indices do not.

The two fundamental measures of residential exposure are the interaction and the isolation index:

The interaction index measures the extent to which members of one group are exposed to members of the other one. It is the minority-weighted average of each spatial unit's majority proportion.

Interaction index $=\sum\left(\mathrm{x}_{\mathrm{i}} / \mathrm{X}\right)\left(\mathrm{y}_{\mathrm{i}} / \mathrm{P}_{\mathrm{i}}\right)$

Where:

$1<\mathrm{i}<\mathrm{n}$

$\mathrm{x}_{\mathrm{i}}=$ the number of members of the group $\mathrm{X}$ in the $i^{\text {th }}$ area, e.g. census tract

$\mathrm{X}=$ the total population of the group $\mathrm{X}$ in the large geographic entity

$\mathrm{y}_{i}=$ the number of members of the group $\mathrm{Y}$ in the $i^{\text {th }}$ area

$\mathrm{P}_{\mathrm{i}}=$ the total population of the $i^{\text {th }}$ area

The isolation index, similar to the previous index, measures the extent to which minority members are exposed only to one other, rather than to majority members, and is computed as the minority-weighted average of each unit's minority proportion:

Isolation index $=\sum\left(\mathrm{x}_{\mathrm{i}} / \mathrm{X}\right)\left(\mathrm{x}_{\mathrm{i}} / \mathrm{P}_{\mathrm{i}}\right)$

Where:

$1<\mathrm{i}<\mathrm{n}$

$\mathrm{x}_{\mathrm{i}}=$ the number of members of the group $\mathrm{X}$ in the $i^{\text {th }}$ area, e.g. census tract

$\mathrm{X}=$ the total population of the group $\mathrm{X}$ in the large geographic entity

$\mathrm{P}_{\mathrm{i}}=$ the total population of the $i^{\text {th }}$ area

Concentration refers to the amount of physical space occupied by a group. A group is said to be residentially concentrated if it occupies a small segment of the total area in a city.

The index of spatial concentration (Delta) is interpreted as the share of group's members that would have to move to achieve a uniform density over all units. 
$\mathrm{DEL}=1 / 2 \mathrm{Z}\left[\mathrm{x}_{\mathrm{i}} / \mathrm{X}-\mathrm{a}_{\mathrm{i}} / \mathrm{A}\right]$

Where:

$1<\mathrm{i}<\mathrm{n}$

$\mathrm{x}_{\mathrm{i}}=$ the number of members of the group $\mathrm{X}$ in the $i^{\text {th }}$ area, e.g. census tract

$\mathrm{X}=$ the total population of the group $\mathrm{X}$ in the large geographic entity

ai $=$ the area of unit $i$

$\mathrm{A}=$ the total area

Finally, clustering is the spatial dimension of segregation and refers to the extent to which areal units inhabited by minority members adjoin one another in the urban space. Clustering is strictly connected to the "checkerboard problem", an important issue in measuring segregation that refers notably to the contiguity between areal units.

All of these indices of residential segregation compare the administrative units (e.g. census tracts) into which the geographical area is divided. From the equivalence between administrative units and neighbourhoods arises two issues: the checkerboard problem and the comparability problem. The checkerboard problem refers to the impossibility of the a-spatial measures of segregation to distinguish between normal widely-distributed settlement areas (like a checkerboard) and a checkerboard where all the black squares are together on one side and the white ones on the other side.

\subsection{Indicators of residential integration}

Most discussions of indicators of integration have articulated an aspiration to include residential integration among key indicators. For example, in the mid-1990s, the Council of Europe's initiative to build a cross-European consensus on measuring integration included residential factors in its recommended indicators: "concentration and segregation in districts/quality of housing/overcrowding” and "proportions in public, rented, and self-owned housing” (1996).

However, the disparities between housing markets, forms of tenure, and available data in different countries have been a barrier to developing common indicators in this area; as most of the housing market is private and since there is little requirement on landlords and home owners to provide standard information to states, national governments tend not to hold extensive data.

The OECD uses three residence-related indicators among its suite of indicators of migrant integration: tenure status, physical description of the dwelling, and cost of housing. On the first of these, for example, 53\% of migrants in OECD countries are owner-occupiers, compared to $71 \%$ among the native-born. At an EU level, the indicators of integration proposed at the Zaragoza ministerial conference of 2010, which put in place a framework for measuring integration across the EU, included "ratio of property owners to non-property owners among immigrants and the total population" (as measured in the EU-SILC database) as one of the core indicators for "social inclusion". ${ }^{1}$ This variable is available for the foreign-born in all EU-27 countries except Romania, for Third Country Nationals in all 27 EU countries except Romania and Slovakia, and can be broken down by gender everywhere except Hungary, Poland, Romania, and Slovakia (Migration Policy Group 2012).

In developing the indicators, the Migration Policy Group has stated in a Discussion Paper that:

\footnotetext{
${ }^{1}$ See Presidency conference conclusions on indicators and monitoring of the outcome of integration policies, Annex to Ministerial Declaration, Zaragoza 2010. NOTE: In August 2013, new indicators were proposed by MPG to augment these Zaragoza indicators: Housing Cost Overburden (EU-SILC), and Overcrowding (EU-SILC).
} 
At the European level, the members of the foreign-born population are three times less likely to own property compared to the general population. This indicator compares the ratio of property owners to non-property owners of foreign born and foreigners in the age group 20-64. While people born in another EU Member State are less likely to own property compared to native-born immigrants, they are still more likely to own property than non-EU immigrants. The situation is slightly more positive for the age group 55-64. The relevance of this indicator is debatable from a social inclusion perspective, for which housing quality and access may be more relevant. Indeed, many recent or temporary migrants have little reason to buy property (ibid.).

OECD research suggests that newer immigration countries such as Ireland, Finland, Greece or Italy tend to have bigger gaps with this indicator than older immigration countries such as Germany (2012).

At a national level, some integration monitors have taken up these indicators. The Migration Policy Group has produced the following summary (2012) of how housing indicators feature in national monitors:

Figure 2. Indicators from national integration monitoring reports:

\begin{tabular}{|l|c|c|c|c|c|c|c|c|c|}
\hline Indicator & EU & Austria & Denmark & Germany & Ireland & Netherlands & Norway & Sweden \\
\hline Housing & $\square$ & $\square$ & & $\square$ & $\square$ & & & $\square$ \\
\hline Property owners & & $\square$ & & $\square$ & & & & \\
\hline Rent & & $\square$ & & $\square$ & & & & \\
\hline Overcrowding & & $\square$ & $\square$ & & & $\square$ & & $\square$ \\
\hline Spatial segregation & & & $\square$ & & & & & \\
\hline Housing cost as share of income & & $\square$ & & & & & \\
\hline Social housing & & & & & & \\
\hline
\end{tabular}

Source: pp.15-16

The Irish national integration monitor, for instance, shows a dramatic gap in the proportion of households that are property owners, between $77.9 \%$ among Irish nationals and $28 \%$ among non-nationals (McGinnity et al 2013P: Table A3 p.9, Table 4.5 p.46). Other monitors use indicators of concentration or of social housing, either instead of or in addition to home ownership. For example, the Dutch national integration monitor includes the indicator "Proportion of individuals from non-Western ethnic minorities in the neighbourhood" as one of the measures of "social contacts". The Danish integration monitor, for example, examines segregation and social housing, disaggregated by gender, 'non-Western immigrants' and particular ethnic groups.

The PROMINSTAT project has provided more detail in its country studies of available variables in each country, which range from tenure to amenities and type of property, to satisfaction with neighbourhood or landlord, to reasons for moving to current residence (e.g. Singleton et al 2010). Few national monitors, however, disaggregate by country of birth, making analysis from a sending country perspective less easy; exceptions are Austria, Norway and Sweden. 


\section{Towards a country of origin perspective}

\subsection{Contrasting outcomes by country of origin}

The types of methodologies introduced in the previous section have been applied to the ways in which different groups within an urban system experience residential concentration differently, with several comparative studies positing both convergences and contrasts between different groups' outcomes. Following the hegemonic role of ethnicity in the American literature, much of this scholarship has focused on differences between ethnic groups. However, there has also been considerable work on explaining differences and similarities between different country of origin groups. This line of inquiry takes us towards the possibility of a sending country perspective on segregation.

For example, the Dutch national integration monitor records the level of residential segregation for different country of origin groups as one of a series of indicators of "social contact". The results (Nijl et al 2005:74) show sharp contrasts by country of origin, with some groups concentrated in what the monitor problematically terms "black" districts (e.g. some African groups as well as those from Pakistan) while others are more likely to be residents in "white” districts (e.g. some East Asian and Middle Eastern groups):

Similarly, in the UK, detailed analysis of housing rental in the Labour Force Survey, although sample sizes are small for migrant groups, reveals significant differences by country of origin, as summarised by Kofman et al:

[Outcomes for] Non-European migrants reflect... varieties of experience, prosperity and entitlement...: those born in Bangladesh, Jamaica, Afghanistan and Somalia, for example, have a higher percentage in social housing than the UK-born, probably reflecting both eligibility (due to refugee status, long residence or citizenship) and poverty. Most other people born abroad have significantly higher percentages in the private rented sector (2009:95). 
Figure 3. Proportion of population living in social housing in Britain, by country of birth, 2005/6

\begin{tabular}{|c|c|c|}
\hline $\begin{array}{l}\text { Rank (in } \\
\text { ascending } \\
\text { order) }\end{array}$ & $\begin{array}{l}\text { Country of } \\
\text { birth }\end{array}$ & $\begin{array}{l}\text { Percentage living } \\
\text { in local authority } \\
\text { or housing } \\
\text { association } \\
\text { housing }\end{array}$ \\
\hline $1=$ & Australia & 5 \\
\hline $1=$ & France & 5 \\
\hline $1=$ & USA & 5 \\
\hline $4=$ & Poland & 8 \\
\hline $4=$ & India & 8 \\
\hline $4=$ & South Africa & 8 \\
\hline $4=$ & Canada & 8 \\
\hline 8 & China & 9 \\
\hline 9 & Italy & 10 \\
\hline 10 & Kenya & 12 \\
\hline 11 & Sri Lanka & 14 \\
\hline $12=$ & Pakistan & 15 \\
\hline $12=$ & Philippines & 15 \\
\hline 14 & Cyprus & 16 \\
\hline 15 & UK & 17 \\
\hline 16 & Zimbabwe & 20 \\
\hline $17=$ & $\begin{array}{l}\text { Republic of } \\
\text { Ireland }\end{array}$ & 21 \\
\hline $17=$ & Uganda & 21 \\
\hline 19 & Nigeria & 29 \\
\hline 20 & Iran & 33 \\
\hline 21 & Jamaica & 35 \\
\hline 22 & Ghana & 39 \\
\hline 23 & Portugal & 40 \\
\hline 24 & Bangladesh & 41 \\
\hline 25 & Turkey & 49 \\
\hline 26 & Somalia & 80 \\
\hline
\end{tabular}

Source: IPPR analysis of LFS, in Kofman et al 2010:99

Conversely, UK research focusing on ownership shows that different ethnic groups have dramatically different rates, with South Asian households considerably more likely than the national average and Black Caribbean and especially Black African households considerably less likely to be homeowners.

In a third example, the Irish national integration monitor shows that the differences among migrants between country of origin groups are as significant as those between migrants and non-migrants, with just $3.3 \%$ of EU12 nationals owning homes compared to 73.15 of A8 nationals. Similar findings are also indicated in the Irish Census, which recorded home ownership as $60 \%$ among UK nationals, 5\% among EU12 nationals, 16\% among African nationals and 20\% among Asian nationals (McGinnity et al 2012:44). In a more geographically focused study, Cristaldi (2002) has measured the segregation of migrants from China, France, Morocco, Peru, Poland, Spain, and Sri Lanka in Rome, showing different degrees of concentration for different country of origin groups.

This type of research agenda has pushed some scholars towards a discussion of different housing integration models for different migrant groups in the same receiving contexts. For example, Ceri Peach (1996) has developed the idea of an "Irish" versus a "Jewish" model of spatial integration, showing that African-Caribbean migrants in the UK have tended to follow 
the former ideal type path while South Asian migrants have tended to follow the latter. Other scholars have instead emphasised the limits of such country of origin models by positing the rise of "region of origin" settlement patterns. For instance, Verdugo has shown that in France during 1969-1999, migrants shifted out of country of origin residential clusters, but re-grouped by larger world region in a dynamic shaped by public housing policy. However, these types of research questions are limited by seeing country of origin as a predictor of integration outcomes in the receiving context, rather than seeing migrants as actors in their own right. In going beyond this limit, we need a transnational rather than methodologically nationalist perspective.

\subsection{Residential integration in a transnational perspective?}

The "transnational turn" in migration studies in the last two decades has opened up a new set of research agendas (e.g. Guarnizo and Smith 1998; Glick Schiller 1999; Vertovec 1999). There has been a shift from the A-B linear conception of migration as a one-time, one-way move from a sending country to a host country, towards a more complex understanding of the migration journey. This has been accompanied by a critique of "methodological nationalism" and an argument that both larger and smaller spatial units might be more appropriate frames for analysing the migrant experience (Beck 2000; Smith 1983; Wimmer and Glick-Schiller 2002). New research paradigms have emerged with this turn. Scholars working in what has come to be called a "transnational" approach have increasingly researched migrant social networks (for instance exploring data on remittances or on hometown associations), migrant livelihood strategies, and migration itself as a networked phenomenon following specific routes between key nodes in larger sub-global migration systems.

This turn has not had a significant impact on the literature on residential segregation, but it nonetheless opens up new ways of conceiving of migrant settlement as part of a larger transnational view of the migration journey, with neighbourhood choice being shaped by a whole web of factors. In particular, the transnational perspective breaks down the traditional divide in migration studies between immigration questions and integration questions, allowing us to relate integration outcomes back to other elements of the migrant journey. Few studies have systematically analysed the relationship between cross-border activities and integration, but those that do suggest that strong transnational links are no barrier to integration in a receiving society and may in some cases facilitate it.

One particularly fruitful area of the transnational approach that is relevant to residential integration is work done on various types of intermediaries in the migration process, which can help us to identify some of the key actors in a transnational residential trajectory. For example, considerable research has been done on various types of agents facilitating regular and irregular migration - see, for example, Peixoto on the "contact people" in Portugal who promise irregular migrants from Brazil or Eastern Europe access to housing as part of a "migration package”, with the housing provided often rented from members of the same informal networks (2008:74). Other types of intermediaries may be located in the formal rather than informal economy, such as the "ethnic estate agents" whom

Wei Li noted as playing a key role in the emergence of contemporary “ethnoburbs” (1998).

A second fruitful area of the transnational approach is the concept of the "migratory career", as developed by Martiniello and others. The migratory career is defined by Cvajner and Sciortino as "a sequence of steps, each marked by events that arfinded as significant within the structure of the actors' narratives and publicly recognised as such by various audiences" (2009). The argument, as articulated by Martiniello, is that: 
the evolution of the migratory career of the new migrants results both from the opportunity structures opened up from above by the institutions (political, economic, social and cultural) in [the receiving] society and by the mobilisation of migrants' resources (social, economic, cultural) from below. Consequently, the concept of a career reconciles both structural approaches and individual approaches. Another hypothesis is that the various groups of new migrants, according to their specific migration path, have different economic and socio-cultural profiles and that these differences influence the way that the migrants mobilise their resources, particularly in their country of origin. The encounter between new migrants' resources and the existing opportunity structures in effect produces the careers of the new migrants (2008:2).

And a third fruitful area emphasised in the transnational literature is the economic flows between sending and destination countries. For instance, affirming an observation made at least as far back as Foerster (1919) in describing Italians in America, many studies over the last three decades have persistently found that real estate investment back home is a major out-going for migrant households. For instance, Gilani et al. found that Pakistani migrant workers spent a majority of their receiving country income on sending country household consumption, with the largest share, $22 \%$ of income, going into real estate. ${ }^{2}$ Summarising much of this literature, the OECD notes that even "when families can afford a suitable accommodation, they may choose to give priority to other aspects of their lives (children's education, proximity to cultural services, etc). This is notably the case for migrants contemplating a return to their country of origin and to an even greater extent for those aspiring to property ownership there.” (2012:59).

Recent work has continued to explore this. For instance, from his research on Moroccan emigrants, Hein de Haas has written about the significance of international migrants' households leading real estate investment and construction activity in the Todra valley. Alongside an acknowledgement of economic motivations (the relative security of a housing investment, which can serve as a form of "life insurance" guaranteeing the migrant's family shelter and even income) He analyses the centrality of housing in terms of "a quest for space, safety, privacy, fewer conflicts and better health". He also emphasises the gendered dimension of this process, whereby women gain personal liberty through establishing nuclear family homes away from their parents-in-law. Similarly, Una Okonkwo Osili (2004), based on a study of Nigerian migrants to the US, argues that providing direct benefits to non-migrating family members, signalling a commitment to a home community and maintaining status and esteem among those remaining behind all more powerfully explain housing investment decisions than the standard investment model of classical economics.

More ethnographic research has teased out the affective texture of these processes. For example, Katy Gardner's research with Sylheti Bangladeshis (e.g. 2002) showed the interrelationship between migration pathways and settlement patterns, with chain migration building up a critical mass of co-ethnics in particular neighbourhoods (specifically Tower Hamlets in London) that in turn encouraged further migration, to the extent that settlement patterns in the receiving country affected migration decisions in the sending country.

Other recent work, drawing on Douglas Massey's work with Mexican migrants in the US (1986), has explored the relationship between transnationalism and integration, although this remains an under-researched topic. For instance, de Haas and Fokkema (2011) have explored the relationship between integration and return migration, based on a on a dataset of four African immigrant groups in Spain and Italy, and found that owning a home in the destination did not affect the likelihood of returning to the sending country, whereas other forms of economic integration in the sending country do reduce the likelihood of return. Valentina Mazzucato (2008) has researched similar questions in relation to Ghanaian migrants in the

\footnotetext{
${ }^{2}$ See also Chandavarkar (1980), or for Morocco Seddon (1981).
} 
Netherlands, with a detailed analysis of how these migrants spend money, including on property in the receiving and sending context. Spending on home ownership in the Netherlands and in Ghana are not inversely related, with many migrants spending on both, showing how transnational commitment and local rooting are not necessarily in opposition.

Cultural dimensions which vary by country of origin feature in some discussions of residential integration. Fereshteh Ahmadi Lewin (2001), for example, shows how the varying meanings of "home" among migrants affect settlement patterns. A rare example of an analysis which from a transnational perspective which focuses on residence is Sutama Ghosh's work on Indian Bengalis and Bangladeshis in Toronto (2007). Ghosh attempts to show that strong transnational ties make a difference to settlement pathways, and the relative density of these among Bangladeshis compared to Indian Bengalis makes a difference to outcomes. Cultural dimensions are highlighted, such as fictive kinship of co-nationals in migration or the sense of obligation (dharma) motivating the provision of shelter to co-nationals. These strong ties are reflected in higher reported satisfaction from Bangladeshis with their first residence in Toronto. However, Ghosh found that these processes did not facilitate home ownership or the move from first accommodation to first permanent residence, as obligations and debts (including contracts with immigration agencies) could keep many Bangladeshis in temporary accommodation longer.

\subsection{Housing pathways}

In some ways mirroring the paradigm shift in migration studies, housing studies have also seen a transition from the more positivist "social physics" of the earlier period to focus instead on how housing choice and constraint are socially constructed (e.g. Payne and Payne 1977, Clapham 2002).

The concept of housing pathways, building on earlier "housing career" approaches, emphasises that choice and constraint operate in different ways in different significant life moments, structured by larger social forces but also including residents' agency. Family formation, life-course moments, and work-related and other formal and informal economic resources and opportunities all play a role, but in the context of particularly shaped housing markets. Clapham (2002) defines housing pathways as "patterns of interaction (practices) concerning house and home, over time and space" (p.63). "The pathway of a household is the continually changing set of relationships and interactions which it experiences over time in its consumption of housing. This includes changes in social relations as well as changes in the physical housing situation” (Clapham 2003:6).

A pathways approach means a turn from statistical models which present a (however sophisticated) static snapshot of residential concentration, to a more diachronic or processual analysis, as time and the life-cycle play a key role in thinking about pathways. The approach was also based on a critique of an earlier "constrained choice" model, which undervalued the role of migrant agency in forging housing careers. A pathways approach foregrounds relationships and interactions, thus showing both migrant agency and capitalist structure.

A particularly useful deployment of this approach was taken in the "Housing Pathways of New Migrants" study in Sheffield, a city in the UK, by Robinson, Reeve and Casey. They worked with four country of origin groups and found significant differences across them:

The careers of migrant workers arriving from Poland paralleled the well-trodden path taken by many new immigrants who arrive into the UK and are reliant upon their own resources to secure and maintain accommodation. In contrast, refugees have a right of access to social housing and this opportunity was found to have proved critical to the efforts of new immigrants from Somalia and Liberia to secure longer-term, permanent accommodation. These respondents tended to be living in relatively unpopular, low-demand accommodation on peripheral local authority estates, in a clear break with the settlement patterns of 
previous immigration streams into the city. The settlement patterns of new immigrants arriving into the UK from Pakistan on a spouse visa were found to be reinforcing the established settlement patterns of this long-standing immigrant population - respondents moving in with a spouse and his/her family (2007:x).

Here is an example of a typical migration pathway from the study.

Figure 4. A typical Liberian housing career, from arrival to secure accommodation

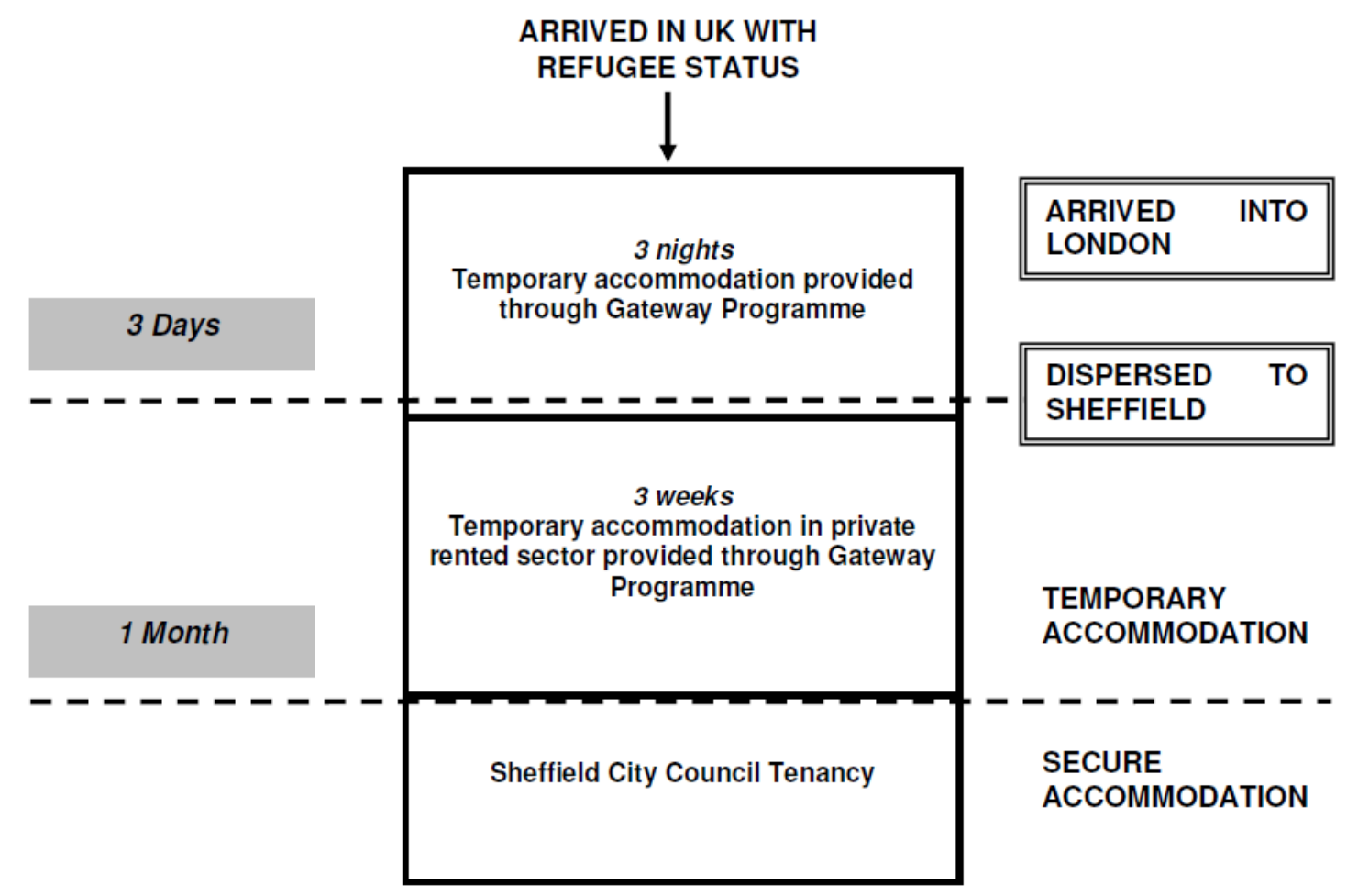

Robinson et al's study gives little space to pre-migration dynamics, but there are some indications of this, for instance in their exploration of changing expectations. For instance, they found that "the realisation that they might remain in Sheffield for longer than originally anticipated was a common mobility trigger among Polish respondents. Upon committing to remain in the UK, housing expectations and aspirations were ratcheted up, with attention focusing on moving into a 'more desirable' residential situation. The arrival of family members, including children, upon making the decision to remain in the UK for a longer time, also prompted mobility." (74) In contrast, shifting intentions were less common among Pakistani and Liberian migrants, who both tended to "hunker down" after settlement (75).

The role of networks and intermediaries, as highlighted in the transnational literature, also emerges occasionally, with "informal support provided by kith and kin, chance encounters with key actors - or gatekeepers - sympathetic to an individual's plight and willing and able to assist [and] third-party advocates able to draw on professional expertise and standing to challenge the decision making of housing agencies such as social landlords” all identified as helping to shift intentions post-migration or otherwise contribute to changing housing pathways. (76) For example, evidence of “a local Pakistani 'accommodation circuit' also emerged, with respondents revealing their disengagement from formal access routes into housing and their reliance on informal alternatives.” (77)

One other recent study which uses the housing pathway concept and also draws on a transnational perspective is by Bonizzoni on Latin American women in Italy (2013). This study, based on interviews, explores the ways in which conceptions of home and the role of women as 
transnational homemakers actively shapes residential strategies in Italian cities. Bonizzoni argues for the gendered dimension of transnationalism: "investments in housing are often directed at repairing, enlarging, ameliorating or buying a house back home: this happens because children are living there, but also because women still think about their permanence in the country as temporary, [because] their overall living conditions (in terms of jobs, housing and juridical status) [are] extremely precarious" but this sense of temporariness lasts longer for the women even after they become well-settled, because of the strong sense of their family roles in relation to home.

Arguably, this sort of approach is highly compatible with a transnational perspective and helps open up a potential research agenda for a sending country perspective on segregation, as will be described further below. A housing pathways analysis would in particular illuminate migrant residential patterns in a time of economic crisis. It also has the value of foregrounding issues of gender and intra-family dynamics, including the active agency of female household members.

\section{Gaps in knowledge}

Key gaps in knowledge, which can potentially be addressed by the INTERACT project, are:

- The extent to which cultural expectations of migrants from different sending contexts affect residential patterns. For example, if there is a "culture" of home ownership, of self-build, or of social housing in the sending context (i.e. a habituated body of practices embedded in the common life of the specific sending context), will this influence housing choice in the receiving context? Inevitably, the extent to which migrants see themselves as permanent or temporary makes a fundamental difference to all the domains of integration, as has been recognised at least as far back as 1976, when Joan Nelson described a continuum between "sojourners" and "new urbanites", who relate differently to the city of settlement depending on their expectations of return. Her "sojourners" include short-term "target”, shuttle, and seasonal migrants intending short stays in the city, as well as those who see migration as a one-off life stage before settling down to adult life at home; for these migrants, housing investment in the reception cost will be little more than the minimum required - and perhaps typically in arrival neighbourhoods and ethnic enclaves where support networks may enable informal housing arrangements, minimising the possibility of residential integration. Understanding these processes requires us to analyse data on the reception context alongside data on the sending context, and ideally the multi-sited collection of data. Drawing on Nelson's observation that the urban conditions in the city of settlement (including the availability of adequate housing or land, discrimination in the rental market, etc.) are a key determining factor in the decision to remain or return, multi-sited research would enable a better grasp of the relative weight of factors at different stages of the migratory career.

- The extent to which cultural and material resources that migrants bring from different sending contexts give them differing market power or access to finance, which structures their housing choices. For example, culturally embedded sources of credit (accessed through kin, religious or hometown networks, for example) might open up opportunities in the housing market otherwise denied when these are absent. The ethnographic literature on transnationalism gives us glimpses of these sorts of issues, but there has been no systematic analysis across country of origin groups.

- The extent to which migrants' residential strategies are already formed pre-migration and the extent to which these strategies are maintained or adapted in receiving contexts. We know that factors already emerging in the sending context make a fundamental difference to residential strategies post-migration, including decisions on where to live, who to live amongst, whether to rent or buy, and the proportion of 
income to be spent on housing in the receiving context as well as housing-related remittances to the sending country. And we know that intentions can change after migration. However, a proper understanding of the extent to which pre-migration factors do or don't continue to make a difference post-migration remains unclear and would require in-depth (including qualitative) research with migrants, and in particular longitudinal study, to develop a better picture.

- The extent to which sending context actors intervene directly in the residential choices of migrants. The academic literature contains almost no examples of case studies of sending context actors directly intervening in residential choices. In terms of flows of financial and other forms of capital, the overwhelming weight of attention in the transnational literature has been on remittances from receiving contexts to sending contexts. Far less attention has been paid to ways in which sending governments invest in the infrastructure of their expatriates and diasporas. In 2005, Moya noted that there have been instances when "local governments [in sending countries] have become sources, rather than recipients, of financial support. Monetary injections from the lately empowered regional governments of Spain and Italy are keeping alive what appeared to be moribund regional and hometown associations in South America and Canada" (2005:856) - although this trend has lapsed somewhat since the economic crisis. Again, understanding this requires focused, in-depth qualitative case study research, and in particular multi-sited research to fully explore the motivations and actions of sending context actors. Specific research questions would include: do some states of origin favor residential concentration in the country of destination through diaspora policies, e.g. by funding associations, cultural centers etc. in specific districts? Or signing bilateral agreements regarding rights of the diaspora in specific regions/towns? By buying land for constructions?

- The extent to which strong or weak transnational ties facilitate or block residential integration. The limited evidence on the relationship between transnational ties and integration (and in particular residential integration) is inconclusive and needs to be developed. It is clear that strong transnational ties do not hinder integration in most socio-economic domains, but it is unclear in other domains. We know that economic integration in the sending context reduces the likelihood of return, but we don't know the extent to which investments in residence and property in the sending country affect migration strategies or integration pathways in the receiving context.

\section{Towards a country of origin perspective on housing pathways and migrant strategies}

As is clear from the above, the literature on residential integration has to date neglected country of origin dynamics beyond approaches which simply see country of origin as a variable. However, we can get glimpses in the literature of some of the key elements of a potential field:

\section{What are the actors involved?}

The actors central to an analysis of residential integration are migrants themselves, best analysed in relation to residential pathways in terms of migrant households, rather than as individuals. However, they are operating as part of complex transnational social fields that include a range of state and non-state actors. These social fields:

- mediate choices migrants make in shaping particular housing pathways, for instance facilitating or blocking access to particular forms of housing; and 
- mediate flows of housing-related capital both from sending contexts to reception contexts (e.g. in the form of capital for investment in initial or subsequent home rental or ownership) or vice versa (e.g. as remittances or investment in real estate back home).

Non-state actors can be classified too in terms of their place in the formal or informal sector, and in terms of their location and focus of attention (in reception or exit contexts or both). The diagram below schematically sets out some of the key actors involved.

In attending to state receiving actors, we also take into account the vital impact of policy on processes of residential integration (see, e.g. Musterd and Fullaondo 2008, Bolt et al. 2006).

Figure 5. Actors in residential integration processes

\begin{tabular}{|c|c|c|c|c|c|}
\hline $\begin{array}{c}\text { ACTORS } \\
\text { \FOCUS OF } \\
\text { ACTIVITY }\end{array}$ & $\begin{array}{c}\text { Reception } \\
\text { context only }\end{array}$ & $\begin{array}{l}\text { Reception } \\
\text { context } \\
\text { primarily }\end{array}$ & Cross-border & $\begin{array}{c}\text { Sending } \\
\text { context } \\
\text { primarily }\end{array}$ & $\begin{array}{c}\text { Sending } \\
\text { context only }\end{array}$ \\
\hline $\begin{array}{l}\text { State actors } \\
\text { Directly } \\
\text { engaged in } \\
\text { housing } \\
\text { pathways }\end{array}$ & $\begin{array}{l}\text { Public } \\
\text { housing } \\
\text { market actors } \\
\text { (e.g. public } \\
\text { housing } \\
\text { authorities, } \\
\text { public } \\
\text { housing } \\
\text { advice } \\
\text { officials) }\end{array}$ & $\begin{array}{l}\text { Settlement/ } \\
\text { reception } \\
\text { programmes } \\
\text { and agencies } \\
\text { (e.g. refugee } \\
\text { integration } \\
\text { programmes) }\end{array}$ & & & $\begin{array}{l}\text { Public } \\
\text { housing } \\
\text { market actors } \\
\text { in sending } \\
\text { context }\end{array}$ \\
\hline $\begin{array}{l}\text { Directly } \\
\text { engaged in } \\
\text { housing- } \\
\text { related flows } \\
\text { of finance }\end{array}$ & $\begin{array}{l}\text { Public } \\
\text { agencies } \\
\text { providing } \\
\text { housing- } \\
\text { related } \\
\text { welfare } \\
\text { benefits }\end{array}$ & & & & $\begin{array}{l}\text { Financial } \\
\text { regulatory } \\
\text { agencies (e.g. } \\
\text { revenue } \\
\text { agencies) }\end{array}$ \\
\hline $\begin{array}{l}\text { Indirectly } \\
\text { engaged in } \\
\text { processes of } \\
\text { residential } \\
\text { integration }\end{array}$ & $\begin{array}{l}\text { Other } \\
\text { institutions of } \\
\text { the local and } \\
\text { national state } \\
\text { in receiving } \\
\text { context }\end{array}$ & & $\begin{array}{l}\text { Sending } \\
\text { country } \\
\text { embassies, } \\
\text { language } \\
\text { schools, and } \\
\text { cultural } \\
\text { centres } \\
\text { Formal } \\
\text { diaspora } \\
\text { engagement } \\
\text { programmes }\end{array}$ & & $\begin{array}{l}\text { Other } \\
\text { institutions of } \\
\text { the local and } \\
\text { national state } \\
\text { in sending } \\
\text { context }\end{array}$ \\
\hline $\begin{array}{l}\text { Non-state } \\
\text { actors } \\
\text { Directly } \\
\text { engaged in } \\
\text { housing } \\
\text { pathways }\end{array}$ & $\begin{array}{l}\text { Private } \\
\text { housing } \\
\text { market actors } \\
\text { (e.g. private } \\
\text { landlords, } \\
\text { real estate } \\
\text { agents) }\end{array}$ & & $\begin{array}{l}\text { Intermediaries } \\
\text { (e.g. people } \\
\text { smugglers) }\end{array}$ & $\begin{array}{l}\text { Household } \\
\text { members left } \\
\text { behind } \\
\text { residing in } \\
\text { property } \\
\text { owned or } \\
\text { rented by } \\
\text { emigrants } \\
\end{array}$ & $\begin{array}{l}\text { Sending } \\
\text { country } \\
\text { private } \\
\text { housing } \\
\text { market actors }\end{array}$ \\
\hline
\end{tabular}




\begin{tabular}{|c|c|c|c|c|}
\hline & & & & $\begin{array}{l}\text { Sending } \\
\text { country } \\
\text { landlords } \\
\text { receiving rent } \\
\text { from } \\
\text { emigrants; } \\
\text { sending } \\
\text { country } \\
\text { tenants } \\
\text { paying rent to } \\
\text { emigrants } \\
\text { Partners or } \\
\text { others } \\
\text { involved in } \\
\text { home country } \\
\text { property } \\
\text { investment } \\
\text { (e.g. rental } \\
\text { agents) }\end{array}$ \\
\hline $\begin{array}{l}\text { Directly } \\
\text { engaged in } \\
\text { housing- } \\
\text { related flows } \\
\text { of finance }\end{array}$ & $\begin{array}{l}\text { Banks, } \\
\text { informal } \\
\text { lenders, } \\
\text { credit unions }\end{array}$ & $\begin{array}{l}\text { Formal and } \\
\text { informal } \\
\text { intra- } \\
\text { community } \\
\text { credit sources } \\
\text { (mutual aid } \\
\text { societies, } \\
\text { lenders } \\
\text { within social } \\
\text { networks) }\end{array}$ & $\begin{array}{l}\text { Formal and } \\
\text { informal } \\
\text { remittance } \\
\text { agents (e.g. } \\
\text { money } \\
\text { transfer } \\
\text { agents, } \\
\text { hawala } \\
\text { agents) }\end{array}$ & $\begin{array}{l}\text { Family } \\
\text { members left } \\
\text { behind and } \\
\text { others in } \\
\text { receipt of } \\
\text { remittances }\end{array}$ \\
\hline $\begin{array}{l}\text { Indirectly } \\
\text { engaged in } \\
\text { processes of } \\
\text { residential } \\
\text { integration }\end{array}$ & $\begin{array}{l}\text { Employers, } \\
\text { customers, } \\
\text { trading } \\
\text { partners, etc, } \\
\text { whose } \\
\text { locations } \\
\text { impact on } \\
\text { residential } \\
\text { choices }\end{array}$ & $\begin{array}{l}\text { Wider } \\
\text { migrant } \\
\text { community } \\
\text { associations, } \\
\text { faith } \\
\text { organisations, } \\
\text { NGOs and } \\
\text { networks } \\
\text { whose } \\
\text { locations } \\
\text { impact on } \\
\text { residential } \\
\text { choices }\end{array}$ & $\begin{array}{l}\text { Cross-border } \\
\text { and } \\
\text { transnational } \\
\text { institutions } \\
\text { (e.g. faith } \\
\text { networks) } \\
\text { whose actions } \\
\text { impact on } \\
\text { settlement } \\
\text { choices }\end{array}$ & $\begin{array}{l}\text { Wider home } \\
\text { context } \\
\text { communities } \\
\text { and networks } \\
\text { whose } \\
\text { locations } \\
\text { impact on } \\
\text { decisions on } \\
\text { return }\end{array}$ \\
\hline
\end{tabular}

In all of these categories, some actors are located purely in the receiving or in the sending context or operate across borders. As Portes (2003) has argued, not all immigrants are transnationals, and thus we would not expect to see individual migrants directly engaging with actors across this diagram; many individual migrants would interact with a limited range of actors in one or another corner of it. However, it is the case that all migrants dwell within a transnational social field, as Faist argues when he notes that "transnational webs include relatively immobile persons and collectives” (2000:191). The three types of transnational social spaces Faist describes - transnational kinship groups, transnational circuits, and transnational communities - are all in play in this field. For example, direct remittances that pay for immobile 
family members' homes in the sending context are key features of kinship groups operating on the principle of reciprocity; real estate speculation in the sending context financed from the receiving context or vice versa is an example of transnational circuits based on exchange; and transnational communities acting out of solidarity might be exemplified in individuals and migrants abroad supporting collective house-building or -improvement projects at home.

\section{How can their actions be classified?}

As the diagram above shows, the actions of these actors - whether forms of reciprocity within kinship collectives, forms of exchange in transnational circuits, or forms of solidarity within communities, or regulatory activities by sending and receiving states - can be classified into direct and indirect influences on housing pathways and related flows of capital. Direct influences include the provision of housing and finance, for example. Indirect influences are very varied, including for instance the clustering of employment opportunities or associational activities that might inform settlement choices in migration, as well as the wider social networks that might influence a return migration decision.

In addition to the spatial dimension (where actors' activities are focused: in the reception or exit context), the temporal dimension is important in classifying their actions, i.e. whether they have an effect pre- or during migration, at point of first arrival, or on an on-going basis.

A more detailed mapping of actions in this field (following Guarnizo's heuristic typology of transnational economic activities, 2003) might identify the beneficiaries of each action (individual migrants, their families and wider social networks, their sending communities, the institutions and agents which capitalise on or take commissions on investments, etc). And it might further identify indicators by which each action could be measured at the micro level of the individual migrant household (proportion of remittances spent on housing, proportion of shelter costs funded from remittances, etc) and at the macro levels of the sending and receiving countries (total flow of finance for housing investment coming from emigrants, proportion of housing stock partly funded by emigrants, etc).

\section{What can actors in the sending country do to overcome the identified difficulties?}

As we can see from the right-hand side of the diagram above, home country actors can play a number of roles in sustaining or depleting the resources with which migrants take advantage of opportunity structures in the receiving context. Family and hometown based associations and networks, as well as other transnational associations (e.g. faith-based), can be key to migrant livelihood strategies. However, the academic literature provides little evidence of how this might play a role in residential strategies specifically.

What are the diverging/converging interests of the sending and receiving countries? What are the strategies of the sending societies to push their interests?

There is some evidence that migrants are able to invest in residence in the receiving context while still making significant remittances to the home country, but the weight of evidence (e.g. Massey 2002) suggests that over time greater financial commitment, including to housing, in the country of settlement depletes the possible resources that can be sent home and diminishes the likelihood of return. This is a key potential divergence of interests between sending and receiving contexts.

Sending countries, at a national level, are increasingly engaged with their expatriate populations, seeing them as key actors in economic and other forms of development. Encouragement to invest in real estate (which provides considerable labour opportunities to 
non-migrants - see Haas 2006) has been a major strategy for sending countries. However, in the literature, there are no discussions of ways in which institutions in sending countries actively intervene in residential strategies in receiving contexts.

\subsection{A new theoretical framework}

The research agenda opened by the transnational perspective and the methodologies used in the housing pathways literature can help us to profoundly re-orient the approach to residential integration. Both perspectives share an emphasis on process rather than pattern: a move away from a static mapping and measurement of a given situation (cf. Simpson 2005).

In such a framework, residential integration would be seen as a process occurring in one of a number of mutually related but relatively autonomous domains of integration. The process of residential integration is conceptualised as a dimension both of a migratory career and a housing pathway as they interact over time. The migratory career and housing pathway are in turn seen as shaped by the relationship between structures of opportunity - constrained by forms of discrimination, regulatory frameworks, and the housing market - and the agency of the migrant household in deploying their own resources - financial, social, emotional and cultural - to make choices. Finally, in understanding migration career, integration pathways, and housing pathways as processes or journeys, we highlight the dimension of time, including historical conjucture, length of stay, and life-course stage, but also collective features of a specific migrant community's trajectory.

In conceptualising these processes as part of transnational strategies, we recognise that aspirations, values, experiences, and resources brought from a sending context are relevant, and that the integration pathway is part of a migratory career that begins long before settlement. It is also recognises that structures of opportunity in the receiving context are also affected at times by actors in the sending country who can intervene. In addition, seeing these processes as part of transnational strategies foregrounds the roles of networks and mediators who connect the sending and receiving context.

Drawing on the typology of actors identified above, a research programme focused on the transnational nature of these strategies would focus on contexts in which countries of origin appear as actors in the integration process. These might include the following elements.

Figure 6. A typology of actions

\begin{tabular}{|l|l|l|}
\hline $\begin{array}{l}\text { Direct influence of CoO } \\
\text { actors on integration } \\
\text { dynamics }\end{array}$ & Trans-national action & $\begin{array}{l}\text { e.g. support/absence of support } \\
\text { for residential clustering through } \\
\text { funding place of worship or } \\
\text { community centre. }\end{array}$ \\
\hline Indirect influence & Domestic action & $\begin{array}{l}\text { e.g. support/absence of support } \\
\text { for real estate investments in } \\
\text { country of settlement or } \\
\text { reinvestments "back home” }\end{array}$ \\
\hline
\end{tabular}

Adapted from Pastore (2013)

This theoretical framework would point to the following research strategy:

- At the micro level of analysis, research would explore individual migrant households' migratory careers, housing pathways, and integration pathways, seen as intertwining with each other as well as shaped both by structures of opportunity (including the legal 
foundations and policy preconditions which facilitate or block integration as well as the socio-economic context including the housing market) and migrants' individual and collective mobilisation of resources (including resources - finance, cultural orientation, social networks - brought from the sending context).

- At a meso level of analysis, research would have to attend to both the patterns characterising country of origin migrant groups in different spatial contexts and the multiple migrant and non-migrant groups who share space in residential neighbourhoods, in order to understand the constitutive role of both country of origin factors and of settlement sites. At this level, we move from housing pathways and migration careers to settlement patterns, including processes of segregation and clustering. Here, the issues identified by Thomas Faist (2000) - social and symbolic ties, and the exchange of social capital through transnational social spaces - are crucial.

- At the macro level of analysis, rigorous comparison across countries of origin and countries of settlement is required to understand the extent to which country of origin variables (economic development, cultural factors, etc.) and country of settlement factors (policy and regulatory frameworks, integration models, etc.) are significant in shaping residential integration. Analysis at this level will identify correlations whose causes can be explored qualitatively at the micro and meso levels.

Such a turn to a more dynamic, process-oriented approach, placing residential integration within a framework of housing pathways which link sending and receiving situations, can raise a series of possible research questions. In this perspective, we can see the extent to which migrants' housing strategies are part of migration strategies. In addition to questions raised earlier about cultural expectations and cultural and material resources shaped in sending contexts, other research questions might include the following.

- Do differing housing tenure, land ownership, household structure models, and finance traditions in sending contexts have an impact on migrant housing pathways?

- What is the role of formal and informal networks and mediators in facilitating migrant access to housing?

- How are home-based actors and political networks (as well as transnational - e.g. family- or hometown-based political networks) mobilised to support migrant residential strategies, including in conflictual contexts such as struggles over access to social housing?

- How do the legal regimes in sending countries - e.g. around currency transfer, foreign investment - have an impact on migrants' housing pathways?

\subsection{Provisional hypotheses on the impact of country of origin actors in the residential integration process}

Drawing on all of the above, we can identify four provisional hypotheses for our research questions.

\section{Hypothesis: Integration in the residential domain loosens transnational ties}

Does integration in the receiving society loosen ties with the sending context? Ethnographic evidence adds some weight to this suggestion, which seems intuitive at first glance. For example, Levitt and Lamba-Nieves, reflecting on long-term work with Dominicans in Boston, note that "While in the early days of migration, people lived near one another, the challenges of Boston's geography and of finding affordable housing mean that community members now often live quite far apart from each other... While they remain committed to helping their community, time is more precious and valuable” (2013:15). However, as Levitt and Lamba- 
Nieves also suggest, this may not be straightforwardly the case; ties with the homeland may be articulated differently in less time-intensive, more efficient ways, for example.

This hypothesis could be tested by observing the correlation between residential integration and remittances to the receiving country or active engagement with hometown associations, with a negative correlation supporting the hypothesis. However, such an analysis would need to be attentive to the importance of harder-to-measure "social remittances" (Levitt 2001, Levitt and Lamba-Nieves 2011) alongside flows of money. Analysis would also have to attend to the context of a particular migrant community: the extent to which the expression of long-distance solidarity is dependent on residential proximity will be diminished by opportunities presented by digital platforms or transit access to hubs of associational activity.

\section{Hypothesis: Sending country actors perceive that integration in the residential domain loosens transnational ties}

Whether or not the previous hypothesis is confirmed by the evidence, it is also intuitively likely that sending country actors - sending states, but also associations based in or focused on the sending context - might perceive it to be true. This would be best tested through interviews with sending country actors, although analysis of relevant documents (e.g. formal strategies for engaging diasporas, speeches of sending politicians aimed at expatriates) might also provide insight.

Hypothesis: sending country actors with an interest in stronger transnational ties act to promote residential integration

If the previous hypothesis is true, it would intuitively follow that those sending country states and other sending country actors that are most concerned with strengthening ties with their emigrant population - e.g. those most dependent on remittances - would act most vigorously to maintain residential integration, if the resources are available. Case study research on examples of sending country actors' interventions could test this hypothesis.

Hypothesis: The specific (local) opportunity structure in the receiving context shapes the possibilities for transnational engagement in residential integration

The preceding hypotheses provide a framework for investigating the motivations of sending country actors to intervene in residential integration processes in receiving contexts. But it is also vital to see how the features of particular places in the receiving context can change the possibilities of integration. Glick Schiller and Çağlar illustrate this across several domains of integration when arguing that where a municipality stands in the larger cartography of transurban systems is a fundamental determinant of the potential for inclusion:

While at the high end of the continuum there are multiple pathways of incorporation... which provide migrants with opportunities to participate in local politics, economy and culture, the range of pathways declines dramatically towards the opposite end of the continuum. At the low end, i.e. in cities in which rescaling efforts have failed to position them competitively at a regional and/or global scale, the variety of pathways for migrant incorporation is much more restricted (2009:195).

If this is true across a range of integration or incorporation domains, it is most fundamentally the case in relation to residential integration, which is heavily constrained and enabled by structural and contingent features relating to place, and in particular by the housing market. Understanding how this works requires a rigorously comparative approach that investigates the opportunity structures in place and the spatial dynamics in play in a range of receiving contexts. Testing this hypothesis, then, calls for a comparative case study approach. 
Hypothesis: The engagement of sending country actors in residential integration has macrosocial consequences in receiving contexts

Glick Schiller and Çağlar argue that the existence and density of particular pathways of incorporation in a municipality in turn impact the municipality itself and its political and economic potential (2009:195). This is just one example of the thesis articulated by Portes (2003) that, in the aggregate, migrants' transnational activities add up to significant effects in both receiving and sending contexts. In the residential domain, this most obviously means effects on the housing markets in both contexts (measurable, for example, by land/house prices and rents and on rates of specific tenure forms), but also on local economies, (the efficacy of) migrant political mobilisations, and forms of bridging and bonding social capital based on migrant associational and cultural life. Quantitatively measuring and attributing causality to such effects would be an extremely challenging task, however, and focused extended case study approaches might be more useful.

\subsection{Methodological approaches}

In conclusion, four different methodological approaches are appropriate in addressing this research agenda, and a combination of these would provide a robust account of residential integration as part of transnational migration.

\section{Multivariate analysis and indicators of integration}

The disaggregation of data on migrant integration, including its relation to residential integration, by country of origin, and a multivariate analysis of key variables remains a key task for integration scholars interested in how country of origin dynamics shape integration. Key data sources are set out in the PROMINSTAT thematic report on housing conditions and include EU-wide datasets (such as EU-SILC on property ownership, which can be disaggregated by country of birth) as well as national datasets (such as Census data). While country-specific datasets often allow more detailed analysis, EU-wide datasets are invaluable for enabling transnational comparison. However, such synchronic methodologies tend to provide a static picture, good for describing the state of integration at a specific moment but poor at explaining integration as a lived process unfolding over time in real place and thus best complemented by longitudinal and more focused qualitative accounts.

\section{Large-scale Longitudinal tracking}

On moving to a process-focused transnational approach to residential integration, one key potential resource would be the use of longitudinal data on migrant trajectories to analyse the factors that shape migrant residential pathways and better understand the role of sending country actors in those. Such data would include material from small-scale qualitative longitudinal studies, large-scale quantitative longitudinal datasets, and the tracking of individual trajectories through linked administrative datasets. Jacobs (2010) has set out some of the resources available in specific EU countries in relation to integration in general. For example, Statistics Finland holds linked datasets that include variables on the housing situation which can be disaggregated by country of birth; in France, the Enquête Longitudinale sur l'Intégration des Primo-Arrivants (ELIPA) project is tracking newly settled migrants, including data on housing choices; Statistics Sweden manages the STATIV database, which longitudinally tracks migrant integration including some housing variables, and can be disaggregated by country of birth (Jacobs 2010:25; Hagström 2009). 


\section{Housing career interviews}

Longitudinal data of a different sort can also be collected retrospectively through biographical recall techniques during interviews, on the model of life history interviews. Similar techniques have been used in transnational migration studies contexts, but here the focus would be on residential history, including decisions about tenure or ownership. ${ }^{3}$

\section{Neighbourhood case studies}

Neighbourhood case studies, ideally including both fine-grained quantitative data collection as well as ethnographic attention to the everyday lived experience of integration, can also help us go beyond the social physics of synchronic methodologies. Where research can explore households from multiple country of origin groups that share space in the same housing markets, a far richer account can be generated of the ways in which specific migratory careers and residential strategies are shaped through local opportunity structures and resource mobilisation. Such research can be resource-intensive - requiring innovative, collaborative methods - and can have limited generalizability. But - as demonstrated by the recent GEITONES and Concordia Discors projects - multi-sited co-operative approaches can generate insightful comparative analysis across cities.

Such a research agenda might enable us to develop more sophisticated accounts of the country and region of origin models already in the literature, and test our hypotheses. It would also generate policy recommendations, in particular given the recent policy neglect of housing as a key element of integration.

\footnotetext{
${ }^{3}$ The methodological discussion in Robinson, Reeve and Casey (2007) provides a useful guide to the issues involved in this approach.
} 


\section{References}

Ager, A. and A. Strang (2008) Understanding Integration: A Conceptual Framework. Journal of Refugee Studies 21 (2): 166-191.

Alba, R.D., and J.R. Logan (1992) Assimilation and stratification in the homeownership patterns of racial and ethnic groups. International Migration Review 26(4):1314-1341.

Andersson, R. (2007) Ethnic Residential Segregation and Integration Processes in Sweden. In Residential Segregation and the Integration of Immigrants: Britain, the Netherlands and Sweden Discussion Paper Nr. SP IV 2007-602, Vienna: IZA 61-90.

Bagguley. P. and Y. Hussain (2006) Conflict and Cohesion: constructions of "community" around the 2001 "riots". In S. Herbrechter and M. Higgins (eds.) Returning (to) Communities. Theory, Culture and Political Practice of the Communal, London: Rodopi

Bergamaschi, A. and I. Ponzo (2011) Concordia Discors: Understanding conflict and integration in European neighbourhoods, GEITONIES Conference, Generating tolerance and social cohesion.

Bijl, R. et al (2005) Integration Monitor, Den Haag: Central Bureau of Statistics.

Bolt, G. et al. (2006] Allochtonen op de woningmarkt: rumetelikje segregation en verhuisdynamiek. In F. van Tubergen and I. Maas (eds.) Allochtonen in Nederland in Internationaal Perspective, Amsterdam: Amsterdam University Press.

Bonizzoni, P. (2013) Home and migration: exploring Latin American women's housing pathways in Italy, International Sociological Association RC 43 Conference 2013: At home in the housing market.

Borjas, G., (2002) Homeownership in the immigrant population, Journal of Urban Economics $52: 448-476$

Bourassa, S.C., (1994) Immigration and housing tenure choice in Australia, Journal of Housing Research 5(1):117-137.

Brubaker, R. (1992) Citizenship and nationhood in France and Germany, Cambridge: Harvard University Press.

Burnett, J. (2004) Community, cohesion and the state. Race and Class 45 (3): 1-18.

Cantle, T. (2001) Community Cohesion: A Report of the Independent Review Team, London: Home Office.

Chandavarkar, A. B. (1980) Use of Migrants' Remittances in Labor-Exporting Countries. Finance and Development 17: 39.

Clapham, D. (2002) Housing Pathways: a Post Modern Analytical Framework. Housing, Theory and Society 19:57-68.

Clapham, D. (2003) Housing and Support in Later Life - A Pathways Perspective. HSA conference University of York April 2003 http://www.york.ac.uk/chp/hsa/papers/spring03/clapham.pdf. Last accessed 28 November 2013.

Constant, A.F., R. Roberts and K.F. Zimmermann (2009) Ethnic identity and immigrant homeownership. Urban Studies 46(9):1879-98.

Coulson, N. E. (1999) Why are Hispanic and Asian-American homeownership rates so low? Immigration and other factors. Journal of Urban Economics 45:209-227. 
Council of Europe (1996) Measurement and indicators of integration Strasbourg: Council of Europe.

Cristaldi, F. (2002) Multiethnic Rome: Toward residential segregation? GeoJournal 58: 81-90.

Cvajner, M. and G. Sciortino (2009) A Tale of Networks and Policies: Prolegomena to an Analysis of Irregular Migration Careers and Their Developmental Paths Population Space and Place 16(3):213-25.

De Haas, H. (2006) Migration, remittances and regional development in Southern Morocco. Geoforum 37 565-580.

De Haas, H. and T. Fokkema (2011) The effects of integration and transnational ties on international return migration intentions. Demographic Research 25(4): 755-782.

Denham, J. (2002) Building Cohesive Communities: A Report of the Ministerial Group on Public Order and Community Cohesion, London: Home Office.

Denton, N. A. and D.S. Massey (1988) The dimensions of residential segregation. Social Forces 67(2):281-313.

Denton, N. A. and D.S. Massey (1989) Racial Identity Among Caribbean Hispanics: The Effect of Double Minority Status on Residential Segregation. American Sociological Review 54(5): 790-808.

Duffy, D. (2007) The housing tenure of immigrants in Ireland: Some preliminary analysis. ESRI Working paper no. 188.

Faist, T. (2000) Transnationalization in international migration: implications for the study of citizenship and culture. Ethnic and Racial Studies 23(2):189-222.

Favell, A. (2001) Philosophies of Integration: Immigration and the Idea of Citizenship in France and Britain, London: Palgrave Macmillan.

Foerster, R. (1919) The Italian Emigration of Our Times, New York: Russell and Russell.

Fortuijn et al. (1998) International Migration and Ethnic Segregation: Impacts on Urban Areas Introduction. Urban Studies 35(3): 367-370.

Gardner, K. (2002) Age, Narrative and Migration: The life course and life histories of Bengali elders in London. London:_Berg.

Ghosh, S. (2007) Transnational ties and intra-immigrant group settlement experiences: A case study of Indian Bengalis and Bangladeshis in Toronto. GeoJournal 68(2/3): 223-242.

Gilani, I. M. Khan, and M. Iqbal (1981) Labor Migration from Pakistan to the Middle East and Its Impact on the Domestic Economy Research Report no. 127, Islamabad: Pakistan Institute of Development Economics.

Glavac, S. M. and B. Waldorf (1998) Segregation and Residential Mobility of Vietnamese Immigrants in Brisbane, Australia. The Professional Geographer 50: 344-357.

Glick Schiller, N. and A. Çağlar (2009) Towards a Comparative Theory of Locality in Migration Studies: Migrant Incorporation and City Scale. Journal of Ethnic and Migration Studies 35:2, 177-202

Glick Schiller, N. (1999) Transmigrants and Nation-States: Something Old and Something New in the U.S. Immigrant Experience. In C. Hirschman, I. Kasinitz and J. DeWind (eds.) The Handbook of International Migration: The American Experience, New York: Russell Sage Foundation. 
Granovetter, M. (1983) The strength of weak ties: a network theory revisited. Sociological Theory 1: 201-233.

Guarnizo, L.E. (2003) The Economics of Transnational Living. International Migration Review 37(3):666-699.

Guarnizo, L.E. and M. I. Smith (1998) The Locations of Transnationalism: Transnationalism from Below. Comparative Urban and Community Research, 6:3-34.

Hagström, M. (2009) Country Report Sweden PROMINSTAT. Malmö: Malmö University.

Heckmann, F., and D. Schnapper (2003) The Integration of Immigrants in European Societies: National Differences and Trends of Convergence, Stuttgart: Lucius \& Lucius.

Hickman, M., N. Mai, H. Crowley (2012) Migration and Social Cohesion in the UK, London: Palgrave Macmillan.

Hirschman, C., (1994) Problems and prospects of studying immigrant adaptation from the 1990 population census: from generational comparisons to the process of "becoming American". International Migration Review 28:690-713.

Jacobs, D. (2010) Monitoring migrant inclusion in the European Union: Towards a longitudinal study of migrants' trajectories, Brussels: EMN.

Joppke, C. (1998) Challenge to the Nation-State: Immigration in Western Europe and the United States, Oxford: Oxford University Press.

Kalra, V. (2002) Riots, Race and Reports: Denham, Cantle, Oldham and Burnley Inquiries. Sage Race Relations Abstracts 27(4): 20-30.

Kohlbacher, J. and U. Reeger (2005) Aus aller Herren Lander? Wien als Studienort und international Bildungsmetropole, Vienna: ISR.

Koopmans, R and P. Statham (2000) Challenging Immigration and ethnic relations politics: comparative European perspectives, Oxford: Oxford University Press.

Kundnani, A. (2007) The End of Tolerance, London: Pluto.

Kofman, E., S. Lukes, A. D’Angelo and N. Montagna (2009) The equality implications of being a migrant in Britain London: EHRC.

Levitt, P. (2001) The Transnational Villagers, Berkeley and Los Angeles: University of California Press.

Levitt, P. and Lamba-Nieves, D. (2011) Social Remittances Revisited. Journal of Ethnic and Migration Studies 37(1): 1-22.

Levitt, P. and Lamba-Nieves, D. (2013) Rethinking social remittances and the migrationdevelopment nexus from the perspective of time. Migration Letters 10(1): 11-22.

Lewin, F.A. (2001) The Meaning of Home among Elderly Immigrants: Directions for Future Research and Theoretical Development. Housing Studies 16(3):353-370.

Li, W. (1998) Anatomy of a New Ethnic Settlement: The Chinese Ethnoburb in Los Angeles Urban Studies 35(3): 479-501.

Logan, J.R., R.D. Alba and Wenquan Zhang (2002) Immigrant enclaves and ethnic communities in New York and Los Angeles. American Sociological Review 67(2):299-322.

Martiniello, M. (2008) Final report - "Research Summary » NOMIBE: New migration and new migrants in Belgium Liege: ULB. 
Massey, D. S. (1985) Ethnic residential segregation: A theoretical synthesis and empirical review. Sociology and Social Research 69(3):315-350.

Massey, D.S. (1986) The Settlement Process Among Mexican Migrants to the United States” American Sociological Review 51(5):670-684.

Maxwell, R. (2006) Muslims, South Asians, and the British mainstream: a national identity crisis? West European Politics 29(4): 736-56.

Mazzucato, V. (2008) The Double Engagement: Transnationalism and Integration. Ghanaian Migrants' Lives between Ghana and the Netherlands. Journal of Ethnic and Migration Studies 34:2, 199-216.

McConnell, E. D., and I. R. Akresh (2008) Through the front door: The housing outcomes of new lawful immigrants International Migration Review 42(1):134-162.

McFarlane, C. and J. Robinson (2012) Introduction - Experiments in Comparative Urbanism. Urban Geography 33(6):765-73.

McGhee, D. (2008) The End of Multiculturalism? Terrorism, Integration and Human Rights, Maidenhead: Open University Press.

McGinnity, F., E. Quinn, G. Kingston and P. O’Connell (2013) Annual Monitoring Report on Integration 2012 Statistical Overview of Integration Dublin: Economic and Social Research Institute and The Integration Centre.

Mesch, G., and R. Mano (2006) Housing attainment of immigrants from the former Soviet Union in Israel: A cost/benefit approach. Housing Studies 21(3):423-440.

Migration Policy Group (2012) Discussion Paper: Social Inclusion \& Active Citizenship indicators for migrant integration, Lisbon: Migration Policy Group.

Morrill, R. L. (1991) On the Measure of Spatial Segregation. Geography Research Forum $11: 25-36$.

Moya, J.C. (2005) Immigrants and Associations: A Global and Historical Perspective. Journal of Ethnic and Migration Studies, 31(5):833-864.

Murdie, R. and L.-E. Borgegård (1996) Immigration, spatial segregation and housing segmentation in metropolitan Stockholm, 1960-95. Working paper No.2. Gävle: Institutet för bostadsforskning.

Musterd, S. and A. Fullaondo (2008) Ethnic segregation and the housing market in two cities in northern and southern Europe: the cases of Amsterdam and Barcelona. Architecture, City and Environment 3(8):93-115.

Musterd, S. and Ostendorf, W. (1998) Urban Segregation and the Welfare State: Inequality and Exclusion in Western Cities, Routledge, London.

Musterd, S. and Ostendorf, W. (2007) Spatial Segregation and Integration in the Netherlands in Residential Segregation and the Integration of Immigrants: Britain, the Netherlands and Sweden Discussion Paper Nr. SP IV 2007-602, Vienna: IZA 41-60.

Myers, D., and S. W. Lee (1996) Immigration Cohorts and Residential Overcrowding in Southern California Demography 33(1):51-65.

Myers, D., and S. W. Lee (1998) Immigrant trajectories into homeownership: A temporal analysis of residential assimilation. International Migration Review 32:593-625.

Nelson, J.M. (1976) Sojourners versus New Urbanites: Causes and Consequences of Temporary versus Permanent Cityward Migration in Developing Countries. Economic Development and Cultural Change 24(4): 721-757. 
Nijman, J. (2007) Introduction - comparative urbanism. Urban Geography 28(1):1-6.

OECD (2012) Settling In: OECD Indicators of Immigrant Integration, Paris: OECD.

Osili, U.O. (2004) Migrants and Housing Investments: Theory and Evidence from Nigeria. Economic Development and Cultural Change 52(4):821-849.

Ouseley, H. (2000) Community Pride not prejudice, Bradford: Bradford Vision.

Painter, G., S.A. Gabriel, and D. Myers (2001) Race, immigrant status, and housing tenure choice. Journal of Urban Economics 49:150-167.

Painter, G., Lihong Yang, and Zhou Yu (2003) Heterogeneity in Asian American Homeownership: The impact of household endowments and immigrant status. Urban Studies 40(3):505-530.

Painter, G., and Zhou Yu (2008) Leaving gateway metropolitan areas in the United States: Immigrants and the housing market. Urban Studies 45(5/6):1163-1191.

Papademetriou, D. and B. Ray (2004) From Homeland to a Home: Immigrants and Homeownership in Urban America, Washington: Fannie Mae Papers.

Papillon, M. (2002) Immigration, Diversity and Social Inclusion in Canada's Cities, Discussion Paper F/27, Family Network, Canadian Policy Research Networks Inc.

Park, R.E. (1925) The City: Suggestions for the Study of Human Nature in the Urban Environment (with R. D. McKenzie and Ernest Burgess), Chicago: University of Chicago Press.

Pastore, F. (2013) Residential integration in a sending country perspective, INTERACT inception meeting.

Pastore, F. and I. Ponzo (2013) Concordia Discors: Understanding Conflict and Integration Outcomes of Inter-Group Relations in Selected Quarters in Five European Cities, Turin: FIERI.

Payne, J., and Payne, G. (1977) Housing pathways and stratification: a study of life chances in the housing market. Journal of Social Policy 6(2): 129-156.

Peach, C. (1996) Does Britain have ghettos? Transactions of the Institute of British Geographers 21(1):216-235.

Peixoto, J. (2008) Migrant smuggling and trafficking in Portugal: Immigrants, networks, policies and labour markets since the 1990s. In C. Bonifazi (ed.) International Migration in Europe: New Trends and New Methods of Analysis Amsterdam: Amsterdam University Press.

Penninx, R., B. Garcés-Mascareñas, and P. Scholten (2005) Policymaking Related to Immigration and Integration: A Review of the Literature of the Dutch Case. Country report on the Netherlands written for Cluster C9 of IMISCOE.

Portes, A., (1998) Social Capital: its origins and applications in modern sociology. Annual Review of Sociology 24: 1-24.

Portes, A. (2003) Theoretical Convergencies and Empirical Evidence in the Study of Immigrant Transnationalism. International Migration Review 37(3):874-892.

Portes, A., W. J. Haller and L. E. Guarnizo (2002) Transnational Entrepreneurs: An Alternative Form of Immigrant Economic Adaptation, American Sociological Review 67: 278-298.

Ritchie, D. (2001) The Oldham Independent Review Panel Report, Oldham: Oldham Independent Review.

Robinson, D. and K. Reeve (2006) Neighbourhood experiences of new immigration: Reflections from the evidence base, York: Joseph Rowntree Foundation. 
Robinson, D., K. Reeve, and R. Casey (2007) The housing pathways of new immigrants, York: The Joseph Rowntree Foundation.

Robinson, D. and A. Walshaw (2012) New Migration, Neighbourhood Effects and Community Change, London: Connected Communities.

Ryan, L. (2011) Migrants' social networks and weak ties: accessing resources and constructing relationships post-migration. The Sociological Review 59: 707-724

Schnapper, D. (1992), L’Europe des immigrés, Paris : Burin.

Schönwälder, K. (2007) Residential Concentrations and Integration: Preliminary Conclusions in Residential Segregation and the Integration of Immigrants: Britain, the Netherlands and Sweden Discussion Paper Nr. SP IV 2007-602, Vienna: IZA 91-100.

Seddon, D. (1981) Moroccan Peasants: A Century of Change in the Eastern Rif, 1870-1970, Folkestone: Dawson.

Simpson, L. (2005) Segregation: A Reply to Johnston, Poulsen and Forrest. Urban Studies 42(7): 1229-1230.

Simpson, L., S. Ahmad, and D. Phillips (2007) Oldham and Rochdale: race, housing and community cohesion, Manchester: Cathy Marsh Centre for Census and Survey Research.

Singleton, A., A. Lenoël and O. Gora (2010) Country Report United Kingdom PROMINSTAT.

Snel, E., G. Engbersen and A. Leerkes (2006) Transnational Involvement and Social Integration. Global Networks 6(3):285-308.

Soysal, Y. (1994) Limits of Citizenship. Migrants and Postnational Membership in Europe, Chicago, University of Chicago Press.

TNS Qual+ (2011) Qualitative Eurobarometer: Migrant Integration Aggregate Report, Brussels: DG-Home.

Vertovec, S. (1999) Conceiving and Researching Transnationalism. Ethnic and Racial Studies 22(2):447-462.

Wacquant, L. (2005) Race as Civic Felony. International Social Science Journal 57(183):136..

Wallman, S. (2011) The Capability of Places: Methods for Modelling Community Response to Intrusion and Change, London: Pluto Press.

Ward, K. (2010) Towards a relational comparative approach to the study of cities. Progress in Human Geography 34(4):471-487.

Wieviorka, M. (2008) L'intégration: Un concept en difficulté” Cahiers Internationaux de Sociologie 125.

Wieviorka, M. (2009) Modeles d'intégration et intégration des modeles? Une étude comparative entre la France et les Pays-Bas. Migrations Société 11(122):25-280.

Wimmer, A. and N. Glick Schiller (2002) Methodological nationalism and beyond nation-state building, migration and the social sciences, Global Networks 2: 301-334.

Wong, D. W. S. (1993) Spatial indices of segregation, Urban Studies 30 (3): 559-572

Yu, Z (2006) A different path to homeownership: The case of Taiwanese immigrants in Los Angeles. Housing Studies 21(4):555-579.

Yu, Z. and D. Myers (2007) Convergence or divergence in Los Angeles: Three distinctive ethnic patterns of immigrant residential assimilation, Social Science Research 36(1): 254-285. 
Zincone, G. (1991) Da sudditi a cittadini, Bologna: Il Mulino.

Zincone, G., and T. Caponio (2005) The multilevel governance of migration-State of the Art Report (Cluster C9), Working Paper WP-3, Amsterdam: International Migration, Integration, and Social Cohesion, Institute for Migration and Ethnic Studies, Universiteit van Amsterdam. 